\title{
MODELING A EUROPEAN \\ COMPETITION AUTHORITY
}

\author{
Alissa A. MEADE \\ It is a daring thing to draw parallels \\ between different legal systems. ${ }^{1}$
}

\section{INTRODUCTION}

Competition policy ${ }^{2}$ is of great importance in the European Union (EU), where it influences "the everyday conduct of business and industry." 3 The original Communities ${ }^{4}$ were founded upon

1. Jens Fejø, Monopoly LaW and Market: Studies of EC CompettTion LaW WITH AMERICAN ANTITRUST LAW AS A FRAME OF REFERENCE AND SUPPORTED BY BASIC MARKET ECONOMICS 8 (1985).

2. The term "competition" is used in Europe as the term "antitrust" is used in the United States. See Robert MERKIN \& KAREN WILliams, CompetTTION LAW: ANTITRUST POLICY IN THE U.K. AND THE EEC 1 (1984).

3. DAN G. GOYDER, EC COMPETITION LAW 4 (2d ed. 1993).

4. There is often some confusion as to the difference between the terms "European Conununity" (EC), "European Umion" (EU), "Common Market" and "European Economic Community" (EEC). The concept of integration, manifested originally in the European Coal and Steel Community (ECSC), was expanded to include all economic markets when the EEC was formed by treaty in 1957. Treaty Establishing the European Econoinic Community, Mar. 25, 1957, 298 U.N.T.S. 11 [hereinafter EEC Treaty]; see also JosEPHINE STEINER, TEXTBOOK ON EC LAW 3 (4th ed. 1994). These three original communities (the EEC, EURATOM (the European Community of Atomic Energy) and the ECSC) are still collectively referred to as "the Communities," "the Community," or "the EC." After the 1986 Single European Act, the term EC was used to signify the collection of states which had dedicated themselves to achieving economic integration. See infra notes 65-69 and accompanying text. In the 1992 Maastricht Treaty, which amended the EEC Treaty, the title of the collective entity was changed to the EU in order to symbolize the heightened commitment to unification embodied in the Maastricht Treaty. See Renaud Dehousse, From Community to Union, in EUROPE AFTER MAASTRICHT: AN Even Closer Union? 4 (Renaud Dehousse ed., 1994). Therefore, "EC" should be used to refer to the pre-Maastricht political entity, "EU" should be used for the postMaastricht political entity, and "the Community" should be used when referring to any one of the original three communities. However, as the original three communities comprise a vast majority of the collective EU, and as the terminology distinctions are subtle, the terms are often interchanged. See D. M. Harrison, THE Organisation of EUROPE: Developing a CONTINENTAL MARKET ORDER xvi (1995). This Note will use the terms "EC" or "Communities" when referring to pre-Maastricht events and "EU" when discussing post-Maastricht events. 
the premise that economic integration could be an effective vehicle by which the nations of Europe could arrive at political unity. ${ }^{5}$ As these Communities flourished, economic integration remained its fundamental, unifying precept. Accordingly, the coordination of the Member States' economies in general, and competition policy in particular, have been of primary importance throughout the development of the EU.

Witl the ratification of the Maastricht Treaty in $1992,{ }^{6}$ the EU Member States strengthened their commitment to economic integration and further committed themselves to political and social integration. Since the ratification of the Maastricht Treaty, the EU has attempted to adopt changes in its institutional framework in order to fulfill these commitments. ${ }^{7}$ Due to its prominence in Union politics, competition policy has been one of the areas in which the Union is considering imstitutional reforms. These reforms nuust be carefully implemented, as they need to be sensitive to the niany factors imtroduced into Umion politics by the proniulgation of the Maastricht Treaty and promote deeper integration among the Meniber States.

Three specific problems must be addressed by any reform of the institutions in charge of European competition policy. ${ }^{8}$ These problems are: 1) the increasing politicalization of competition policy; 2) the extant institutions' lack of transparency (i.e., the degree to which the workings of the institution can be observed by the public) $;{ }^{10}$ and 3) the failure of the subsidiarity primciple, which re-

5. See loukas tsoukalis, The New European ECONOMY: The Politics and ECONOMICS OF INTEGRATION 15-16 (1991).

6. Treaty on European Union, Feb. 7, 1992, 31 I.L.M. 247 [hereinafter Maastricht Treaty].

7. See Dehousse, supra note 4, at 5-15.

8. See Stephen Wilks \& Lee McGowan, Disarming the Commission: The Debate over a European Cartel Office, 32 J. COMMON MKT. STUD. 259, 265 (1995) (describing the "[t]hree central problems [that] dominate" the EU's competition system) [hereinafter Wilks \& McGowan, Disarming].

9. See, e.g., François Duchêne, Less or More Than Europe? European Integration in Retrospect, in THE POLITICS OF 1992: BEYOND THE SINGLE EUROPEAN MARKET 9, 19-22 (Colin Crouch \& David Marquand eds. 1990) (suggesting that, while the Union has made notable economic achievements, political unity has failed); Caroline Jackson, The European Community and the Challenges of the 1990s: Change and Competitiveness, in EUROPE AFTER MAASTRICHT: AMERICAN AND EuROPEAN PERSPECTIVES 41, 41 (Paul Michael Lutzeler ed., 1994) (observing that some commentators believe that Union disunity in the face of "international political challenges" has led to a failure of the Union "experiment").

10. See Diane P. Wood, User-Friendly Competition Law in the United States, in PRO- 
quires that the EU act only where it is explicitly allowed by the terms of the Maastricht Treaty or where an objective can not otherwise be sufficiently obtained except by united Community action. ${ }^{11}$

Numerous suggestions for competition reform liave arisen. One proposal would create a politically independent competition authority geared to overconie these fundamental problems. This plan is generally referred to as the European Cartel Office (ECO) proposal. The inost promiment variant of the ECO proposal suggests implementing, on the European level, an institution whicl emulates the German conipetition regime. ${ }^{12}$ This Note argues that basing European reform solely upon the German system would be ill-advised and that there are valuable lessons to be learned from many other nations' systems, including the American system.

Before discussing the ECO proposal im detail, Part I of this Note will outline the relevant European institutional framework. Part I also traces the history of the European conipetition system, noting how political influences have affected the ebb and flow of pressures for competition reform. This Note attenipts to assess the ECO proposal's prospects for success by analyzing existing national competition systems as models upon whicli the ECO autliority might also be based. ${ }^{13}$ Thus, Part II presents a brief overview of the competition systenis of Germany, France, the United Kingdom, ${ }^{14}$ and the United States, and then draws from eacli lessons

CEDURE AND ENFORCEMENT IN E.C. AND U.S. COMPETTTION LAW 8, 10 (Piet Jan Slot \& Alison McDonnell eds., 1993). The principle suggests that "regulatory agencies should be obliged to make public as much as possible of the information and reasoming upon which their decisions and actions are based." See DAMIEN NEVEN ET AL., MERGER IN DAYLIGHT 174 (1993).

11. See infra note 91; see also Maastricht Treaty, supra note 6, art. G.4, 31 I.L.M. at 257; see also George A. Bernann, Subsidiarity and the European Community, in EUROPE AFTER MAASTRICHT: AMERICAN AND EUROPEAN PERSPECTIVES 139 (Paul Michael Lutzeler ed., 1994) (arguing that the subsidiarity principle cannot maintain "the proper balance between Community and member state governance for all occasions").

12. See Wilks \& McGowan, Disarming, supra note 8, at 260 . Under this proposal, the competition authority would be politically independent, sufficiently staffed and funded, and charged with specific aspects of competition enforcement. Its independence would ostensibly make it more efficient, and it could assune over half of the European Commission's cases, thereby reducing the burden on the Commission. See id. at 269.

13. As the emphasis of this work is imstitutional reforn, a discussion of the underlying substantive aspects of antitrust law is beyond the scope of this Note.

14. These Member States' systems will be discussed because these are the only EU Member States with sufficient political and economic clout to serve as an accepted model in the EU framework. 
useful in the European context. Part II argues that, while the German system might serve as a loose framework for competition reform, a system based predominantly on the German regime would fail. Therefore, before impleinenting reform in competition policy, the EU should look to supplement a German-based systein with ideas from other nations. The United States, with its deep divisions between federal and state antitrust regimes, offers numerous lessons regarding federahism and transparency to the European systen1. The United Kingdonı has a healthy competition regime that varies greatly from the German model while offering some useful ideas, such as an independent monopohes and mergers commission.

Part III then reviews the outlook for European reform, concluding that an ECO should be instituted in the future but that sucli dramatic reform should not proceed without consideration of the inany alternative structures for such an entity. However, the conipetition system is in need of some immediate change; Part III therefore suggests some stopgap reforms of the current systein as alternatives to the immediate implementation of inore ambitious, long-term ECO reform.

\section{THE History AND EVOLUTION OF THE EUROPEAN COMPETITION REGIME}

\section{A. The Institutional Framework}

The institutional framework of the European Union is fundamentally democratic, and its federal structure allows for all of the functions of the branches of government familiar to Americans. ${ }^{15}$ However, there are vast differences between the American and European systems of government, and the four fundamental EU institutions-the Council of Ministers, the Commission, the European Parliament and the European Court of Justice-are very different fron $\mathrm{m}$ stitutions in the United States. For example, the only popularly elected body, the European Parliament (EP), is given little practical authority in the legislative process and serves mostly in a supervisory and advisory capacity. ${ }^{16}$ While the EP has

15. See Thomas C. Fischer, THE EuRopeanization of AMERICA: What AMERICANS NEED TO KNOW ABOUT THE EUROPEAN UNION $45-47$ (1995).

16. See D. LASOK, LAW AND INSTITUTIONS OF THE EUROPEAN UNION 219 (6th ed. 1994); FISCHER, supra note 15, at 203-05. Because the EP has served essentially an advi- 
recently been given greater authority in the legislative process, the legislative function is primarily carried out by the Council of Ministers (the Council). ${ }^{17}$ The executive role is often associated with the European Commission, but the Commission is a melange of all the branches' functions. ${ }^{18}$ While the Commissioners convene periodically, the majority of the daily work of the Commission is done by civil servants. These employees are inembers of one of the Commission's twenty-three advisory departments, or Directorates-

sory function there has long teen detate that the EU suffers from a "democratic deficit." See id. at 203-05. With the implementation of the 1992 program, however, the EP has achieved a significantly larger role in the legislative process. See id. at $45-47$. In many circumstances, the EP can approve, amend or reject proposals for legislation. See id. Further, it is expected that the EP will be atle to further augment is powers. See id.

17. The Council consists of one representative from each of the Member States. EEC Treaty, supra note 4, art. 146, 298 U.N.T.S. at 69 . There are no standing "councilmen"; the representatives change according to the subject matter to be discussed. The Council is empowered "to ensure co-ordination of the general economic policies of the Member States; the power to take decisions'; and take dispositions on 'the implementations by the Commission of the acts adopted by Council."' LASOK, supra note 16, at 197. Its power "to take decisions" is central to the Council's role in the Union decisionmaking framework. See id. at 196. This power has been interpreted to give the Council authority in legislative matters, the duty to oversee the implementation of the Treaty's policies, the enactment of the budget, and the representation of the Umion in foreign affairs. See id. at 197. Thus, despite the brevity of its constitutional mandate, in reality the Council holds great influence in regular Union matters. See id.

18. The Commission's executive power derives from its role as the delegate of the Council for the purposes of law-making and from its duty to ensure that the rules of the Treaties are appropriately apphed. EEC Treaty, supra note 4, art. 155, 298 U.N.T.S. at 71. The Commission also performs legislative functions, in that it is actively engaged in proposing and formulating legislation. LASOK, supra note 16 , at 192 . It even exercises some powers of review, as it is charged with reviewing cases and institutions in order to ensure "the functioning and development of the Common Market." EEC Treaty, supra note 4 , art. 155, 298 U.N.T.S. at 71. Finally, the Commission also executes representative, financial and administrative functions. LASOK, supra note 16, at 193 . Thus, unlike any entity in the United States, it is a full-service authority. The Commission is a college of representatives appointed by the Member States' governments to serve five year terms. See Josephine SHAw, EUROPEAN COMMUNITY LAW 54 (1993). Two Commissioners are drawn from each of the larger Meniber States, and one from each of the smaller states. Id. The Commission operates as a collegiate body with the whole Commission taking responsibility for each of the Commissioners' acts. See LASOK, supra note 16, at 188. Accordingly, legislative proposals by the Commission tend to be made only after extensive investigation and advice. See id. at 190 . These investigations are undertaken by the Commission's enormous body of European civil servants. See SHAw, supra, at 54. The Directorates-General, which are large auxiliary staffs organized by subject matter, carry out the substantive analyses denranded by the Conmission. See LASOK, supra note 16, at 189. In 1993, the Commission staff consisted of mostly DG personnel and numbered 13,790 . Id. 
General. ${ }^{19}$ Directorate-General IV (DG-IV) is responsible for competition matters. ${ }^{20}$ The European Court of Justice (ECJ) carries out the judicial functions of the EU and exercises supervisory control over the separations of powers among Union institutions and between the Union and Member States. ${ }^{21}$ The strength afforded to the ECJ has proven to be an effective counterbalance against the political institutions in the Union. ${ }^{22}$

19. See SHAW, supra note 18 , at 54 .

20. See ivo Van Bael \& Jean-Francois Bellis, Competrtion LaW of the EUROPEAN COMMUNITY 6 (3d ed. 1994).

21. See SHAW, supra note 18 , at 51 .

22. The ECJ consists of sixteen judges who are unanimously elected by the Member State governments. See LASOK, supra note 16, at 244. As the Court is entirely created by the Treaties, its jurisdiction cannot extend beyond the bounds delineated in them. However, in 1963, the ECJ interpreted the language of the Treaty to sanction implicitly the doctrine of direct effect which greatly expanded the number of suits which could be brought before the Court. See Case 26/62, Van Gend en Loos v. Commission, 1963 E.C.R. 1, 1 C.M.L.R. 82 (1963); Joseph H.H. Weiler, The Transformation of Europe, 100 YALE L. J. 2403, 2413 (1990-91). For an expanded discussion of the direct effect doctrine, see T.C. HARTLEY, THE FOUNDATION OF EUROPEAN COMMUNITY LAW 195-234 (3d ed. 1994). This doctrine provides: "Community legal norms that are clear, precise, and self-sufficient ... must be regarded as the law of the land in the sphere of application of Community law." Weiler, supra, at 2413. Specifically, this means that any law which is determined to have "direct effect" creates a cause of action which is enforceable by the ECJ both between an mdividual and a Member State and between individuals. See HARTLEY, supra, at 195-97.

Article 177 of the EEC Treaty vests jurisdiction in the ECJ to make a "preliminary decision" on the interpretation of the Treaty, on the validity and interpretation of acts by the Union's institutions including the European Central Bank, and on the interpretation of Council statutes (where provided). See EEC Treaty, supra note 4, art. 177, 298 U.N.T.S. at 76-77. These rulings arise when Member States' courts request a clarification on a specific point of European Union law. See LASOK, supra note 16, at 307. These requests may only be brought by Member State courts and tribunals and cannot be dismissed without reason. The Court has taken its duty to elucidate the requested question of law seriously and will not dismiss unless the request was too vague or was not direct application of Union law. See id. at 308-11.

Other matters of jurisdiction are relatively straightforward. Article 173 of the EEC Treaty allows appeals to the ECJ based upon claims of ultra vires, nifringement of due process, infringement of the Treaty, a general principle of EU or international law, or misnse of powers. See Maastricht Treaty, supra note 6, art. G, 31 I.L.M. at 293 (amending Article 173 of the EEC Treaty). The application of Article 173 is himited by Article 173(2) which states that natural and legal persons may only challenge decisions addressed to then1, or regulations or decisions addressed to others which are of "direct and individual concern" to them. LASOK, supra note 16 , at 119. Since 1989, jurisdiction to hear appeals by private individuals in conpetition niatters has been transferred to the Court of First Instance. See id. at 276-80.

Article 175 of the EEC Treaty allows enterprises and individuals to challenge Union institutions for a failure to neet Treaty requirenients. See Maastricht Treaty, supra note 6, art. G, 31 I.L.M. at 293 (anending Article 175 of the EEC Treaty). Article 169 


\section{B. The Foundation of the System}

The fundamental elements of the European competition system were established in Articles 85 and 86 of the EEC Treaty. ${ }^{23}$ These Articles left to politicians and to the courts the task of creating imstitutions to apply and to enforce the Articles' inandates. ${ }^{24}$ While the EEC Treaty made it clear that the new regime would extend beyond the scope of its predecessor, the Treaty of Paris, ${ }^{25}$ it was not precise as to exactly how far the jurisdiction of

provides for prosecution of Member States that fail to meet obligations imposed by the Treaty. See EEC Treaty, supra note 4, art. 169, 298 U.N.T.S. at 75. Finally, Article 210 provides that the European Community is a legal person. See id at 210, 298 U.N.T.S. at 86. As such, it can sue and be sued in tort actions. The federalized system created im the European Union reserves most judicial review for the Member States and allows European causes of action in only specific situations. For example, the creation of Article 177 rulings was intended to allow the Member States to retain cases which touch upon Union law by allowing the ECJ to nrake preliminary rulings on EU issues in national cases. See LASOK, supra note 16, at 68. However, while these European causes of action are meant to work in cooperation with the national law regimes, there is often overlap or conflict. See, e.g., id. at 565. The systems co-exist but are subject to the doctrines of autonomy, direct applicability and supremacy. There is a heightened degree of coordination between the national and federal systems in competition matters-for instance Member States are consulted on proceedings involving their citizens-but there nonetheless remains an overlap in enforcement jurisdiction. See id. Because most competition cases affect both domestic and European trade, they could be disposed of before either Meinber States courts or before the ECJ. See id. at 564. In the seminal Dyestuffs case, Case 14/68, Walt Wilhelm v. Bundeskartellamt, 1969 E.C.R. 100, the ECI determined that the parallel application of national and Communty conipetition law is permissible as long as it does not prejudice the uniform application of Community law. See id. While parallel proceedings are possible, any sanction imposed by one authority is discounted froin any second sanction. See LASOK, supra note 16, at 566. When contradictory determinations are made, the supremacy doctrine is applied and the ECJ's decision will prevail. See id.

23. EEC Treaty, supra note 4, arts. 85, 86, 298 U.N.T.S. at 47-49; See GOYDER, supra note 3, at 22 . Article 85 begins: " 1 . The following shall be deemed to be incoinpatible with the Common Market and shall hereby be prohibited: any agreements between enterprises, any decisions by associations of enterprises and any concerted practices which are likely to affect trade between the Member States . . . EEC Treaty, supra note 4, art. 85, 298 U.N.T.S. at 47-48.

Article 86 states that: "action by one or more enterprises to take improper advantage of a dommant position within the Common Market or within a substantial part of it shall be deemed to be incompatible with the Cominon Market." Id. art. 86, 298 U.N.T.S. at 48 .

Both of these fundaniental articles prohibit anticompetitive actions that are "imcoinpatible with the common market" and that "may affect trade between the Member States." Id. arts. 85-86, 298 U.N.T.S. at 47-48.

24. See HARTLEY, supra note 22 , at 3-4.

25. Treaty Establishing the European Coal and Steel Community, Apr. 18, 1951, 261 U.N.T.S. 140 (Treaty of Paris). 
the new laws would extend. ${ }^{26}$ However, the framers did make clear that, unlike many domestic competition systems, ${ }^{27}$ the European system would not ouly protect competition, but would also promote market integration. ${ }^{28}$

When the EEC was founded in 1958, it was based upon the premise that Europe's best chance to ensure a peaceful future lay in inextricably intertwining the markets of the Member States. ${ }^{29}$ As the Member States recovered from the devastation of World War II, integration toward a common economic market became a means by which Europe could achieve political unity througlı economic growth. ${ }^{30}$ Additionally, as the global balance of power became increasingly bipolar, economic imtegration was viewed as a means by whicli Europe could obtain the unity needed to compete effectively against the economic and political powers of the Umited States and the Soviet Union. ${ }^{31}$ Competition policy would therefore support this fundamental integrationist policy, ${ }^{32}$ and as Europeans grew to recognize the pohtical significance of integration, the competition system garnered considerable legitimacy by supporting fundamental policy. ${ }^{33}$

In the post-war era, Germany was the only Member State operating a widely respected competition system, ${ }^{34}$ and according-

26. See GoYDER, supra note 3 , at 28-31.

27. Id. at 24-25.

28. Barry E. Hawk, Antitrust in the EEC-The First Decade, 41 FordHAM L. REV. 229, 231 (1972) ("Single market integration, and the elimination of restrictive practices which interfere with that integration, is the first principle of EEC anti-trust law, and is basic to the treaty objective of a "common market."').

29. See SHAW, supra note 18 , at $22-28$.

30. See The Politics of 1992: Beyond the Single European Market vii (Colin Crouch \& David Marquand eds., 1990) (calling the history of the European Community a "paradox" because the EC's goal of political integration was to be accomplished through economic integration).

31. See RichaRd MAYNE, THE RECOVERY OF EUROPE 1945-1973: From DEVASTATION TO UNITY 219-246 (1990).

32. The EEC Treaty explicitly stated that the aims of the EEC are, first, the creation of a common market, and second, the progressive coordination of the economies of the Member States. See EEC Treaty, supra note 4, arts. 9-116, 298 U.N.T.S. at 18-61. "It shall be the aim of the Community [to establish] a Common Market and progressively approximat[e] the economic policies of Member States . . . " Id., art. 2, 298 U.N.T.S. at 15 .

33. See GoYDER, supra note 3, at 18-20.

34. The first German antitrust law, the Act Against Unfair Conpetition, was enacted in 1909. See MARTIN HEDENHAIN \& HANNES SCHNEDER, GERMAN ANTITRUST LAW 17 (4th ed., 1991). This law, however, was widely ignored, and the German economy became increasingly cartelized throughout the first half of the century. See id. at 17-18. This car- 
ly most Europeans were skeptical about competition principles at the formation of the Community. ${ }^{35}$ Consequently, the integrationist rationale lent much-needed legitimacy to European competition policy. ${ }^{36}$ The integrationist rationale lielped to make the Member States more willing to accept competition policy, which, in turn, allowed the Commission to establisli a strong coinpetition practice with minimal Member State involvement. ${ }^{37}$ The significance of this legitimacy also manifested itself institutionally as integration inolded the Community's competition structures and "generated the conceptual framework for the developinent and application of its substantive norms." 38

\section{The Court of Justice Takes the Lead}

Given Europe's initial skepticism toward competition policy, ${ }^{39}$ it is not surprising that the Council, the legislative and most politicized of the Community institutions, delegated great authority to the Commission in this field. After long debate, ${ }^{40}$ Regulation 17 was passed in 1962, delegating wide powers over coinpetition policy to the Commission. ${ }^{41}$ The EEC Treaty did not specify which entity would assunie the leading role in conipetition policy, and the Commission wanted to establish a central role for itself while inarginalizing the role of the national authorities. ${ }^{42}$ Regulation 17

telization culminated in a fully planned and controlled economy under the Nazi regime. See id. Under Hitler, all economic policy determination was centralized in the federal government which supported the strong industrial cartels. See Kari HARDACH, THE POLITICAL ECONOMY OF GERMANY IN THE TWENTIETH CENTURY 53-59 (1980). In order to neutralize the cartelized economy, the occupying Allied forces in Germany instituted an antitrust system following the war. See COMPARATIVE LAW OF MONOPOLIES 347 (E. Susan Singletion et al. eds., 1996).

35. See HARDACH, supra note 34 , at 148-50.

36. See David J. Gerber, The Transformation of European Community Competition Law?, 35 HARV. INT'L L.J. 97, 98 (1994).

37. Id. at 107. While integration was politically popular, a sound economic rationale exists for using integration as the basis of the competition system. See CFRISTOPHER W. BELlaMY \& GRAhaM D. CHILD, COMMON MARKET LAW OF COMPETTTION \& 1-073 (Vivien Rose ed., 4th ed. 1993).

38. See Gerber, supra note 36 , at 98.

39. See supra notes $34-35$ and accompanying text.

40. The Council would not yield its powers without considerable debate-Regulation 17 was promulgated only after nearly a half decade of wrangling over the drafts. See GOYDER, supra note 3, at 35-38.

41. Council Regulation 17/62, 1962 J.O. (204), amended by Council Regulation 59/62, 1962 J.O. (1655), Council Regulation 118/63, 1963 J.O. (2696), and Council Regulation 2822/71, 1971 O.J. (L 285).

42. See Grant W. Kelleher, The Common Market Antitrust Laws: The First Ten 
did so, utilizing a number of devices to augment the Commission's powers vis-à-vis the Member States. ${ }^{43}$

These provisions contributed to two important characteristics of European competition law. First, the Commission established its own ability to "legislate" regarding competition matters on the basis of the powers granted to it by Regulation $17^{44}$ Second, Regulation 17 lielped shield DG-IV and the Commission from political influence by minimizing the Member States' role im competition policy. ${ }^{45}$

However, while in the early Sixties the Commission appeared to liave effectively liarnessed the national authorities and to have placed itself in a dominant position, the so-called "empty chair crisis" brought the Commission's efforts to a halt. ${ }^{46}$ The crisis was sparked by French President Cliarles de Gaulle's demands to decrease the supranational powers of the EC; as a result, the Treaty was amended to effectively require a unaminous vote im Council

Years, 12 ANTTrRUst BULL. 1219, 1221 (1967).

43. For example, Article 9(3) invokes the Member States' competencies only when "the Commission has not initiated any procedure" for investigation or enforcenient under Articles $85(1)$ or 86 . See id. at 1221 . This provision has discouraged national authorities from acting where even a chance of Community enforcement existed, since such acts would have been moot upon the Commission's inquiry. The Commission also affirmed its dommance by the establishment of Article 9(1), under which the Commission is empowered to determine individual exemptions on a case-by-case basis and to administer the block exeniptions required to alleviate the Commission's enormous caseload. See LASOK, supra note 16, at 561-62. Moreover, Regulation 17 bolstered the already significant powers of the Commission by establishing the notification procedure, which requires that the Member States notify the Commission of any agreement that might violate Article 85. Council Regulation $17 / 62$, supra note 41 , arts. 4 \& 5.

44. See Gerber, supra note 36 , at 107.

45. See id.

46. The crisis was rooted in a number of political issues that came to a climax in 1965. See DEREK W. URWN, COMMUNITY OF EUROPE: A HISTORY OF EUROPEAN INTEGRATION SINCE 1945 107-15 (2d ed. 1995). Three issues-the "democratic deficit" in the European Parliament, the establishment of a system by which the Community could raise its own revenues, and the agricultural subsidies budget-were problems. See id. Despite the Community's successes to this point, French President Charles de Gaulle was strictly against any increase in its supranational powers. See id. De Gaulle's refusal to accept any measures which increased the supranationality of the Community clashed with the other Meniber States' desire for imtegration. See id. The conflict culminated in the French Foreign Minister's refusal to attend the 1965 Council of Ministers, which he was supposed to chair. See id. In order to appease the French demands, the six Member States signed the "Luxembourg Compromise" in January 1966; the compromise, in effect, required Council unanimity in most matters and allowed any Member State to exercise a veto on matters it believed were of "vital national interest." Id. In return, France agreed to return to the Council. See id. 
decisions. ${ }^{47}$ Consequently, the political machinery of the Community was paralyzed, and the European Court of Justice (ECJ) had to step in to fill the void that was left by the Commission's inability to operate under such constraints. ${ }^{48}$

Taking advantage of the circumstances, the ECJ quickly worked to expand its influence in conipetition niatters by freely enunciating broad principles which articulated a strong integration rationale and reflected a behef that a large role for the Commission was necessary for effective conipetition enforcenient. ${ }^{49}$ The ECJ had not been subject to the political process which had crippled the Commission, and thus enjoyed relatively unbridled authority. In this political vacuum, the ECJ was able to demonstrate its diligence in competition niatters and to forge a reputation as a "motor of integration." Despite the emerging role of the ECJ, coordination and umity between it and the Commission was needed. Fortunately, they shared the same ideas and values-including the justification of competition enforcement by integrationist goals-mand these values helped to mold the institutions' identities during the next two decades. ${ }^{51}$ The European competition regime thus developed three distinguishing traits: centralized enforcement, juridical rule and a continuing dedication to integration. ${ }^{52}$

\section{Competition Policy Stumbles}

The consideration of any reform in the Seventies and early Eighties was waylaid by the "Euro-pessimism" that ensued during this period. ${ }^{53}$ With the collapse of the Bretton Woods monetary system and the emergence of OPEC came economic instability and the Community's first recession since its establishment. ${ }^{54}$ This eco-

47. See URWIN, supra note 46 , at 107-15.

48. Because the Commission was unable to pass much legislation during this time, the ECJ was looked to for maintenance of the EC's competition system. See Gerber, supra note 36 , at $108-09$.

49. See id. at 109.

50. Id. at 144.

51. See id. at 108-09.

52. See id. at 114.

53. See TSOUKALIS, supra note 5 , at 1 .

54. In 1944 the Bretton Woods system was established, based upon English sterling and the U.S. dollar. Allan M. Williams, THE Western European ECONOMY: A GEOGRAPHY OF POST-WAR DEVELOPMENT 40-41 (1987). Because of the U.K.'s balanceof-payments problems, the system came to rest primarily on the U.S. dollar. See id. Accordingly, when the dollar was devalued in 1971 to compensate for the United States' 
nomic crisis hit Europe soon after the EC's first expansion-in 1973, the United Kingdoin, Ireland and Denmark entered the Community. ${ }^{55}$ The political toll of the recession nranifested itself in the early 1980s, which were characterized by serious political disunity among the Member States. ${ }^{56}$ The Community was suffering from "Euro-scierosis" 57 and little was done to advance Community goals. For example, an important proposal by the Commission to introduce merger regulation was submitted in 1973 but received minimal attention from the other institutions. ${ }^{58}$

With most of the community's institutions disabled by this political quagmire, the ECJ continued to carry out competition policy. In fact, the ECJ had begun to depart brazenly from some established principles of European competition jurisprudence. In the Continental Can case, the ECJ condenmed the inere acquisition of power through a merger despite the lack of evidence that there had been an abuse of that power. ${ }^{59}$ Until this case, European doctrine clearly lield that Article 86, which prohibits the abuse of dominant power, was inappropriate for merger regulation. ${ }^{60}$ While the ECJ has not used Article 86 to prohibit a merger since Continental Can, it continued to widen the scope of its jurisdiction by holding that "other behavior with anti-conpetitive effects is contrary to Article 86 if there is an appreciable effect on coinpetition." 161 This unprecedented expansion of judicial powers created a tension in the relationship between the ECJ and the Commission. Much to the chagrin of the Commission, the ECJ had expanded the substantive law while simultaneously narrowing the law's practical effect by annulling decisions based on imsufficient

skyrocketing deficit, the Bretton Woods system broke down. See id. Two years later, several Arab countries formed an oil embargo against the West. See id. Between October 1973 and January 1974, oil prices quadrupled, leading to serious economic distress. See id. at $45-46$.

55. See id. at 37.

56. See George A. Bermann et al., Cases and Materials on European ComMUNITY LAW 13 (1993).

57. This term was coined by German economist Herbert Giersch to refer to apparent rigidities in the European labor and product markets. See TsouKALIS, supra note 5, at 1. 58. See id. at 98 .

59. Case 6/72, Europemballage Corp. v. Commission (Continental Can), 1973 E.C.R. 215, 242-45.

60. Article 85, which prohibits concerted action in restraint of trade, was thought to be the appropriate law for merger regulation. See ADVOKATERNE BREDGADE 3 ET AL., European Economic Community, in MERGER CONTROL IN THE EEC 217, 231 (1988).

61. See id. at 232. 
evidence. This shift might be viewed as a trade-off reflecting the political climate; the ECJ's progress in the substantive law was symbolically imiportant in the dismal European political arena, while its insistence upon strict adherence to rules of procedure eased the economic consequences of this expansion. ${ }^{62}$

\section{E. The Commission Returns to the Driver's Seat}

The Court of Justice's bold maneuvering was curtailed in the late 1980s after a number of important institutional changes. In response to the discordant atmosphere that liad developed, the EC Member States asked the Commission to outline a plan and a timetable for the achievement of a fully integrated inarket. ${ }^{63}$ The Commission responded by drafting an advisory document called the White Paper, which became a blueprint for achieving integration by $1992 .{ }^{64}$ The White Paper was the basis for the Single European $\mathrm{Act}^{65}$ (SEA), which aimed to reestablish cohesion among the Member States and to refocus the institutions upon integration. ${ }^{66}$ The most important effect of the Act was to reintroduce qualified majority voting into Council decisionmaking for almost all decisions. ${ }^{67}$

The Single European Act was psychologically significant for the Community; ${ }^{68}$ the establishment of a time frame within which to achieve the integrated market gave many Europeans new faith in the Community's dedication to its economic goals. It also formally established a Commumity-wide commitinent to integration of not just economic, but also of social and political policies. ${ }^{69}$

This renewed commitinent proved to have considerable effect upon competition policy. The psycliological boost inspired by the SEA came just as Europe was recovering from the economic and political unrest of the Seventies. ${ }^{70}$ The junction of these factors

62. See Gerber, supra note 36 , at 118.

63. See S. F. GOODMAN, THE EUROPEAN COMMUNITY 168 (1990).

64. See HARRISON, supra note 4 , at 55.

65. 25 I.L.M. 506.

66. See GOODMAN, supra note 63 , at 168 .

67. Unanimity was retained only for the accession of new members and the enunciation of new policies. See URWIN, supra note 46, at 232-33; Single European Act art. 6-12, 25 I.L.M. 508-510.

68. See URWIN, supra note 46, at 230-44.

69. See Single European Act, arts. 23, 30, 25 I.L.M. 513, 517-18.

70. See supra notes 53-58. 
contributed to great gains in market activity. The latter half of the Eighties saw enormous growth in the number of mergers, acquisitions, joint ventures, and other cooperation agreements. ${ }^{71}$ In response to this climate, the Commission again began to apply pressure on the Council to agree to a merger control proposal. ${ }^{72}$ Although calls for the promulgation of a merger regulation system had been muted during the unrest of the $1970 \mathrm{~s},{ }^{73}$ this new period of economic growth and increased market sophistication made the adoption of a merger regulation proposal seemingly imperative.

In 1987, the ECJ decided the Philip Morris/Rothmans case, which suggested the possibility of using Article 85 alone to prohibit acquisitions of a minority share in a coinpeting enterprise. ${ }^{74} \mathrm{Al}-$ though the parties adequately anended their agreement and the Commission closed the investigation, the case nonetheless created de facto merger regulation. It is now widely accepted that the Commission brought this case partially in order to send a signal to the Council that if it did not pass a inerger control regulation it would "suffer the consequences of a wide interpretation of the precedent." Ac Accordingly, the Council proceeded rapidly to pass a regulation instituting Commission competency in mergers-fourteen years after the original proposal. ${ }^{76}$

The introduction of inerger control has changed Europe's competition regime in a number of ways which could prove to be important in the future of coinpetition reform. First, the Commission has secured a central role in European competition law by reserving for itself essentially all discretion in dealing with mergers. ${ }^{77}$ Second, because merger control is especially sensitive to pohtical pressures, the merger regulation systein, while generally

71. See TsOUKALIS, supra note 5 , at $91-96$.

72. See BREDGADE ET AL, supra note 60 , at 221.

73. See supra notes $53-58$ and accompanying text.

74. Cases 142/84 and 156/84, British American Tobacco Co. and R.J. Reynolds Inc. v. Commission, 1987 E.C.R. 4487, 4576-77.

75. See VAlENTINE KORAH, AN INTRODUCTORY GUIDE TO EEC COMPETTTON LAW AND PRACTICE 212 (4th ed. 1990); see also GOYDER, supra note 3, at 390-92 (describing the impact of the Phillip Morris decision).

76. NEVEN, supra note 10, at xi.

77. The Commission has a virtual monopoly on notification, investigation, negotiation, decisionmaking and political review, while the ECJ is limited to judicial review of the Commission's decisions and thus plays virtually no role. See Council Regulation 4064/89, 1996 O.J. (C 194) (1989); NEVEN, supra note 10, at 1-2. 
praised for its efficiency and flexibility, receives strong criticism for the inconsistency of its decisions. ${ }^{78}$

\section{F. The Talismanic 1992: Where Do We Go from Here?}

Although the Commission and the ECJ have been motivated to promoted competition policy by the economic benefits of free competition, ${ }^{79}$ economic integration has been the primary reason for establishing a Community-wide competition regime. After developing under such an assuniption for forty-five years, European competition law is now llaving trouble maintaining its identity as the importance of economic integration seems to be waning. ${ }^{80}$ With the arrival of the exalted "1992," the date by which economic integration was to occur, the integrated market rationale was rendered invalid, because the goal upon which the Commission had based competition policy had seemingly been achieved. ${ }^{81}$

78. For example, during the first seven years of the merger control regulation, only one merger was prohibited and the Commission's ability to effectively apply the regulation for which it had lobbied so hard began to be doubted. See Gerber, supra note 36, at 136. The Aérospatiale/Alenia/de Havilland case was the sole case in which the ECJ denied a merger. See Case IV/M042, Atrospatiale-Alenia/De Havilland, 4 C.M.L.R. M2 (1992). While this case was viewed by some as evidence that the Commission was taking seriously its role to enforce merger regulation, it was more widely regarded as a political embarrassment. See Wilks \& McGowan, Disarming, supra note 8, at 265. Both France and Italy lobbied in hopes of allowing the merger, which was impermissible under the current EU thresholds. See Gordon Borrie, Personal View; Time for a Euro-MMC, FN. TIMES, Nov. 11, 1991, at I16. Further, a number of officials from DG-III, Industrial Policy, also lobbied publicly in hopes of influencing the Commission's decision. See id. at I16. Overall, the case clearly demonstrated the political pressure and lobbying to which merger decisions were subject. See GoYDER, supra note 3, at 508-09.

79. Although this might appear to be an unjustified extension of competition policy, apparently the promotion of the economic advantages of fair competition was envisioned as a secondary goal at the inception of the system. See Jean-François Verstrynge, The System of EEC Competition Rules, in EXPLOITING THE INTERNAL MARKET: CO-OPERATION AND COMPETITION TOWARD 1992 1, 2-3 (Peter J. Slot \& Michael H. Van der Woude eds., 1988). The inclusion of these economic principles has also helped establish credibility in the system because, when necessary, the courts have made decisions based on the promotion of favorable economic factors which were not directly linked to the integration of the market, but which were nonetheless beneficial. See id. at 4-6. The EC competition policy has also stressed lower prices, improved technological progress and wider product markets. See id. at 1, 2-3. These principles, however, remained a secondary rationale, while economic integration continued to be the lodestar which guided the system. See id.

80. See infra notes $82-83$ and accompanying text.

81. In 1987, the Single European Act (SEA) set a time frame within which the Community was expected to reach full integration. See URWIN, supra note 46, at 231. December 31, 1992 was set as the target date for the completion of the integrated mar- 
While some commentators may still debate whether integration has fully been achieved, ${ }^{82}$ it apparently no longer holds the preeminent role in European politics that it once did. The ratification of the Maastricht Treaty has established that the Member States' commitment to social, political and foreign policy integration must be pursued simultaneously with the purely economic integration embraced by DG-IV. ${ }^{83}$ Thus, the European competition regime is conflicted. The cornerstone of competition doctrine, economic integration, is eroding, while pressures to emphasize other pohicies which often grate against the strongly integratiomist goals of Community competition, such as industrial policy and technology advancement, are mounting. This shift in policy has begun to create tension ainong the different factions represented in the Commission and has led to an increase in lobbying and politicking in the competition field ${ }^{84}$ Although the Commission is the established front-runner in competition policy, it must navigate the European competition regime through a stormy sea filled with these concerns. The ECJ, on the other land, must establish a new identity and a new role in this competition regime. The question remains, however, whether the Commission and the ECJ can accomplish these tasks without destabilizing the system as it has emerged.

In sum, with the increase in national authority, the lessening role of the ECJ, and the strong but identity-less ${ }^{85}$ Commission at the helm, Europe is ripe for imstitutional reform in competition. The success of merger regulation and the level of respect with which DG-IV is generally regarded ${ }^{86}$ bode well for reform. Reform, however, should only be implemented after careful consideration of different options and after a determination of the reform options that would be most effective.

ket and consequently the phrase "Europe 1992" took on considerable psychological significance. See id. at 230-44. Although 1992 has come and gone, most commentators are reluctant to say that the integrated market has been fully achieved. See id. at 245-62; TsOUKALIS, supra note 5, at 88; Jackson, supra note 9, at 41-51.

82. See HARRISON, supra note 4, at 68-69, 90.

83. See Maastricht Treaty, supra note 6, art. G.3, 31 I.L.M. at 257. The so-called "three pillars" of the European Union, economic integration, foreign security coordination and social cooperation, are each regarded as important for paving the way to a fully integrated Europe. See HARTLEY, supra note 22, at 8.

84. See supra notes 53-61 and accompanying text.

85. That is, without its original driving goal of economic integration.

86. European merger control has been praised for being efficient, for creating consolidated jurisdiction, and for providing flexibility in a disciphine which is rife with confiicting factors. See Wilks \& McGowan, Disarming, supra note 8, at 264. 


\section{MODELS FOR AN INDEPENDENT CARTEL OFFICE}

\section{A. The European Context}

In exploring reforn options, certain characteristics of the European competition regime must be considered. First, the competition policy regime is one of the most important mstitutions in the European Union, and any reform will have repercussions throughout the framework of the Union. ${ }^{87}$ Accordimgly, coinpetition reform will be subject to political factors which are outside the conventional ambit of competition policy. This is especially true considering the EU's limited budget. ${ }^{88}$ Every dollar, pound, deutschmark, or Ecu spent in one Directorate-General will be coveted by the others.

Second, since the Maastricht Treaty states that the European Union aspires to reach full-not just economic-integration, it requires that the Meinber States not only coordinate economic policy, but also monetary, security, and cultural policies. ${ }^{89}$ The Commission, then, must tread between these newly emphasized considerations and the need to reestablish an identity for competition policy in Europe. This position might prove to be precarious, as the pursuit of pure competition often does not coincide with the furtherance of other interests, such as industrial policy, monetary integration, or cultural reform. ${ }^{90}$

Third, by including the subsidiarity primciple in the Maastricht Treaty, the EU institutions made a constitutional commitment to the Member States to exercise jurisdiction only when it was not otherwise appropriate for the Member States to adjudicate an issue in their own domestic systems. ${ }^{91}$ This principle, however, is

87. See id.

88. See PIERRE MAILlet \& PHILIPPE ROLlet, INTÉgration Économique EUROPEENNE: THEORIE ET PRATIQUE [EUROPEAN ECONOMIC INTEGRATION: THEORY AND PRACTICE] 297-301 (1988). For a general explanation of the European budgetary system, see id. at 286-301.

89. See Maastricht Treaty, supra note 6.

90. Some commentators question whether it is appropriate for DG-IV to take these other factors into account when deciding issues of competition. See, e.g., R. B. BOUTERSE, COMPETITION AND INTEGRATION-WHAT GOALS COUNT? EEC COMPETITION LAW AND GOALS OF Industrial, MONETARY, AND Cultural Policy 113-15 (1994).

91. The subsidiarity principle is laid out in the Maastricht Treaty:

The Community shall act within the limits of the powers conferred upon it by this Treaty and of the objectives assigned to it therein.

In areas which do not fall within its exclusive competence, the Community shall take action, in accordance with the principle of subsidiarity, only if and in so 
inconsistent with the EU's deepening commitment to integration and supranationality. Consequently, the tension between greater integration and Member States' desire to assert their autonomy is a constant factor in European politics, and legislation in the Umon often reflects this tension. ${ }^{92}$ Because institutional bodies such as the Commission and European Parhiament represent national as well as EU interests, European legislation must be a compilation of compromises im order to satisfy the varying interests of the EU's diverse constituencies. ${ }^{93}$

Fourth, EU institutions are often subject to accusations of increasing politicalization, lack of transparency and failure of subsidiarity. ${ }^{94}$ These faults plague numerous European institutions, including the Commission and the DG-IV ${ }^{95}$ and are often used as the yardsticks with which to measure the competence of an institution. Therefore, these factors are essential elements of any analysis of competition reform options.

\section{B. European Union Member States' Systems}

The biggest debates concerning competition reform have centered around proposals for an independent competition authority called the European Cartel Office. ${ }^{96}$ This proposal is consistent with a general movement toward the decentralization of authority away from Brussels, the EU capital, while keeping it within the Union's competence. ${ }^{97}$ An independent federal banking authority,

far as the objectives of the proposed action cannot be sufficiently achieved by the Member States and can therefore, by reason of the scale or effects of the proposed action, be better achieved by the Community.

Any action by the Community shall not go beyond what is necessary to achieve the objectives of this Treaty.

Maastricht Treaty, supra note 6, art. G.4, 31 I.L.M. 257-58.

92. See, e.g., URWN, supra note 46 , at 113 (discussing the Luxembourg Compromise); id. at 229 (discussing the negotiations over the SEA and the Member States' actions as they were "mindful of the past tendency for proposals to be watered down by national governments").

93. See id. at 245-62; Duchêne, supra note 19, at 9.

94. See Wilks \& McGowan, Disarming, supra note 8 , at 265 ; see also supra notes 9-11 and accompanying text.

95. See generally Robert Rice, Business and the Law: A Burden on Business, THE FIN. TMMES, Feb. 1, 1994, at 16 (arguing that delay, legal uncertainty, inadequate safeguards, failure to supervise the judicial process, and ossification plague the Commission).

96. See Wilks \& McGowan, Disarming, supra note 8, at 259-60.

97. A number of European agencies and centers have been established away from Brussels in hopes of moving them out of the political hierarchy. For example, the European Environmental Agency in Copenhagen, the European Central Bank in Frankfurt 
the European Central Bank, was recently establislied in Frankfurt and lias encouraged proponents of an independent competition authority. ${ }^{98}$ The primary rationale for establishing an ECO has been the advantage of removing certain functions from the direct control of the Commission. ${ }^{99}$ In light of the increasing pohitical pressures in forming competition policy, depoliticizing the Commission and DG-IV may have considerable advantages. ${ }^{100}$ Several models for a depoliticized ECO have been suggested. In an effort to sift out which means could be most effective, a comparative analysis of the numerous domestic competition regimes is useful; each regime can be thought of as a different model upon which the Commission might base European reform. The German, French, Britisl and American systems are those most often discussed as models for European reform.

1. The German System. A model based on the federal German competition authority, the Bundeskartellamt (BktAmt) ${ }^{101}$ is the most commonly suggested model for the ECO. ${ }^{102}$ This

and the European Agency for the Evaluation of Medicinal Products to be located in London are all agencies which were instituted outside of Brussels in hopes of reducing direct political intervention. See id. at 262 n.4.

98. While the ECB provides a possible model for an economic regulation authority which has been successfully decentralized, there are reasons to believe that such a model may not be easily apphed to competition regulation. The loss of efficiency in transferring authority to a new agency may not be worth the advantages of the new institution. This is especially true when the original authority was as widely respected as DG-IV. See id. at 262 .

99. See id.

100. For example, this would increase transparency, which has been lacking in the Commission's procedures. The lack of transparency in the European system derives from the fact that in many cases the Commission wears two hats-that of prosecutor and judge. Therefore, its opimions are scrutinized only when a case is appealed to the European Court. See, e.g., Claus-Dieter Ehlermann, Reflections on a European Cartel Office 32 COMMON MKT. L. REV. 471, 474 (1995) (arguing that transparency would be improved by creating a European Cartel Office whose decisions can be appealed to the Coinmission). Some critics complain that the Commission can justify its decisions in a manner that is never exposed to review. See NEVEN, supra note 10, at 214-26.

101. Non-German commentators often abbreviate the Bundeskartellamt as BKA, but, for Germans, "BKA" is the acronym for the German equivalent of the FBI. To avoid confusion, this Note will use the abbreviation BktAmt.

102. See generally NEVEN, supra note 10, at 233; Andre R. Fiebig, The German Federal Cartel Office and the Application of Competition Law in Reunified Germany, $14 \mathrm{U}$. PA. J. INT'L Bus. L. 373, 404 (1993); Wilks \& McGowan, Disarming, supra note 8, at 260; Stephen Wilks \& Lee McGowan, Discretion in European Merger Control: the German Regime in Context, J. EUR. PUB. POL'Y. March 1995, at 41, 64 (1995) [hereinafter Wilks \& McGowan, Discretion]. 
model is useful because Germany is widely respected for its vigorous enforcement of competition principles. ${ }^{103}$ While both Germany and the UK have long adhered to the notion that competition should be enforced by legal means, ${ }^{104}$ the UK did not join the Community until 1973 and consequently, Germany has dommated the formation of European competition pohicy.

The BktAmt is the most important of the five Gerinan institutions responsible for enforcenent of the German competition law, the GWB. ${ }^{105}$ It has jurisdiction in all cases that have effect beyond one of the federal states (Länder) ${ }^{106}$ While the BktAmt is technically subordmate to the Federal Minister for Economics (FME), in practice, policy decisions are usually made by the BktAmt. Such decisions are given to the FME only when they have some overt political significance. ${ }^{107}$ Furthermore, the BktAmt exercises direct cartel authority except in three specific situations, ${ }^{108}$ in which direct political responsibility for a decision is considered desirable and the cartel authority is exercised by the FME. ${ }^{109}$ Otherwise, the FME only indirectly exerts its influence over the BktAmt through its ministerial duties. ${ }^{110}$

103. See James MaXeiner, Policy and Methods IN German AND American ANTITRUST LAW 1 (1986).

104. Germany promulgated the original German Law Against Restraints of Competition (Gesetz gegen Wettbewerbsbeschrankungen) [hereinafter GWB] in 1958. See MARTIN HEIDENHAIN \& HANNES SCHNEIDER, GERMAN ANTITRUST LAW 17-18 (1991). For an English translation of the Act as amended, see $i d$. at 161-343. In the United Kingdom, the Monopolies and Restrictive Practices (Inquiry and Control) Act was passed in 1948. See PaUl H. GuENAULT \& J. M. JaCKSON, THE CONTROL OF MONOPOLY IN THE UNITED KINGDOM 8-10 (1974).

105. See Fiebig, supra note 102, at 374-75.

106. As the average German Land is about the size of an American county, only those cartels which are very localized do not come under federal jurisdiction. See Fiebig, supra note 102, at 376.

107. See MAXEINER, supra note 103 , at 92.

108. These three situations are: 1) when a cartel agreement which is prohibited by Section 1 of the GWB does not fall within one of the exceptions in Sections 2-7 and the FME finds the "the restraint of competition is necessary for predominating reasons concerning the general economy and the common welfare," HEIDENHAIN \& SCHNEIDER, supra note 104 , at $171 ; 2$ ) when an export cartel is an agreement or resolution which "serve[s] to protect and promote exports, provided that they are limited to the regulation of competition in markets outside the territory in which this Act applies," id. at 169; and 3) when ministerial authorization is allowed because "the restraint of competition is compensated by the overall economic advantages." Id. at 209.

109. See MAXEINER, supra note 103, at 97.

110. The FME can exert ministerial authority in several ways: 1) by issuing directives to the BktAmt office, see HEIDENHAIN \& SCHNEIDER, supra note 104 , at $265 ; 2$ ) by 
Although the BktAmt has the practical power to dictate competition pohicy, it technically falls within the competence of the cabinet of the FME. ${ }^{111}$ The BktAmt takes a legalistic approach to competition issues, while the FME, as a political government cabinet, does not. ${ }^{112}$ This creates tension ${ }^{113}$ because the FME pursues national economic pohicies that sometimes do not promote free competition. ${ }^{114}$ Accordingly, the BktAmt's decisions do not always coincide with the FME's interests. The German system was established with these countervailing powers because it was envisioned that the authority with the most direct effect on competition should not be one subjected to excessive political lobbying or to public opinion, but rather one which applies the laws and pohcies in a highly legalistic manner. ${ }^{115}$ The BktAmt's independence from both the business community and the government las been instrumental in its success. ${ }^{116}$

A European system based on the BktAmt would be an improvement over tlie present system in a number of ways. The BktAmt's pohtical independence is the most iniportant characteristic wlich advocates of an ECO hope to duplicate in the European system. ${ }^{117}$ This proposal has substantial appeal in light of the increased pohticalization of European Union institutions. Most lobbyists in conpetition matters are hired by the industrial or commercial sectors, which promote neither free conpetition nor con-

making appointments to the decision divisions, see id; 3) by attaching its opinions to the BktAmt's biannual report, see id. at 267 ; and 4) by resolving conflicts between the BktAmt and other governmental authorities responsible for regulated industries, see id. at 257-59. See Fiebig, supra note 102, at 392-94; MAXEINER, supra note 103, at 96-97.

111. See Fiebig, supra note 102, at 392.

112. This is most evident in the FME's use of its ministerial authority to approve nergers which the BktAmt had prohibited when the FME believes that the public interest outweighs the restraint on competition that results from the nerger. See GWB $\S 24(3)$; see also Fiebig, supra note 102, at 392-93.

113. See id. at 395.

114. See id. at 394.

115. Because the BktAmt's staff and management are not elected, the institution is generally considered to be apolitical. See Wilks \& McGowan, Discretion, supra note 102, at 44.

116. As a symbol of its political autonony, the BktAmt has maintained physical independence from the FME. The BktAmt is located in Berlin, the FME's offices are in Bonn. With the FME's pending nove to Berlin, the BktAmt will be relocating to Bonn to maintain the separation. See Wilks \& McGowan, Discretion, supra note 102, at 48.

117. See Wilks \& McGowan, Disarming, supra note 8, at 260-63. 
sumer welfare, but their particular interests. ${ }^{118}$ Keeping these special interest groups distanced from the actual policymakers has a logical appeal.

Most supporters of a German model suggest a modified twotiered system sphitting competency between the ECO and the Commission. ${ }^{119}$ All notifications, imvestigations, and decisions would be based on highly legalistic tests for which the ECO would use strictly competition-based criteria, while the Commission would undertake political review and either the Commission, the Courts or both would hear appeals. ${ }^{120}$ Arguably, this arrangement would heighten public awareness and consequently would make competition policy more transparent. ${ }^{121}$ This, im turn, would create greater accountability in decisionmaking because the Commission would know that any illegitimate decision to overrule an ECO judgment would be publicly exposed and would elicit considerable criticism. ${ }^{122}$

However, in the context of the European system, many of these factors would not necessarily translate into a superior system. While mimisterial imtervention has been minimal in Germany, ${ }^{123}$ sucl solidarity might not arise in the Community's political culture. ${ }^{124}$ German politicians tend to have relatively uniform views on competition law, and despite the so-called "natural relationship of tension"125 between the FME and the BktAmt, in reality relatively little conflict has arisen. ${ }^{126}$ The European system, im contrast, is inherently conflicted. Conflict exists between the Member

118. Interview with Julie S. Breitfeld, M.A. candidate in German economics and history at the Georgetown Umiv. Inst. of Foreign Affairs in Washington, D.C. (May 8, 1996).

119. See NEVEN, supra note 10, at 232-33; Wilks \& McGowan, Disarming, supra note 8 , at 269.

120. See NEVEN, supra note 10, at 232-38; Wilks \& McGowan, Disarming, supra note 8 , at 269.

121. See Wilks \& McGowan, Discretion, supra note 102, at 60 .

122. See id.

123. The FME has appealed only seven BktAmt decisions. See Wilks \& McGowan, Disarming, supra note 8 , at 269 n.13.

124. One Commission official commented, "The only way to make [an ECO] work would be to put it in Berlin."' NEVEN, supra note 10, at 242 n.1.

125. Fiebig, supra note 102 , at 392 ; see also notes $111-115$ (describing the inherent relationship of tension).

126. See MAXEINER, supra note 103, at 95-97 ("[I]nformal and regular cooperation between the Federal Cartel Authority and the Ministry is said to be the rule; the president of the Federal Cartel Authority regularly participates in the meetings of the section chiefs of the Ministry in Bonn."). 
States and the European Union, between the different factions and interest groups in the institutions of the Uinon, and between the Member States' representatives in each of these institutions. These conflicts would likely upset the balance between the ECO and the Commission.

Furthermore, while there is little disagreenent about whether the European system lacks transparency, the political insulation of an ECO may not be the best solution to this problem. The legalistic basis of the German system, while efficient, is nonetheless pohtically unresponsive. Perhaps Germany's tendency to "accentuate legal or economic criteria and [to] try to deny pohitics" is best explained as a response to its historical experiences with regimes which demied legal boundaries. ${ }^{127}$ However, to attempt to entirely exclude political influence from economic analysis is unrealistic. ${ }^{128}$ Economic issues are often preeminent in politics; conversely, politics inust lave its place in economic affairs.

For example, it has been argued that it is desirable for independent agencies such as the proposed ECO to exercise complete discretion in economic pohicy. ${ }^{129}$ This argument, however, fails in two fundamental respects. First, since the creation of an independent agency is in essence a delegation of political power in order to distance the agency froin direct popular influence when desirable ${ }^{130}$ the agency's independence fundamentally derives froin political power. Unless the agency is allowed to exercise some political discretion, its policies will be entirely divorced from the political will of the constituency that created it. Second, while the basic role of a regulatory agency is to enforce compliance, directly policing every case is mipossible. ${ }^{131}$ Therefore, an agency inust be willing to be flexible and to bargam when the outcoine of enforcement will be outweighed by the administrative burden. A system in which entities can police themselves is best equipped to balance the need for independence and the need for political responsive-

127. See Wilks \& McGowan, Discretion, supra note 103, at 62 .

128. See id. Bernard Crick's theory of political analysis suggests that practical analyses (such as legal and economic ones) should not be divorced from theoretical analyses of the political scene. See Susan Saunders Vosper, Bernard Crick's Conception of the Political: Reflections on the Relationship of a Theory and a Practice, in DEFENDING POLITICS: BerNaRd CRICK AND PluRALISM 144, 144-62 (Ian Hampsher-Monk ed., 1993).

129. See Wilks \& McGowan, Discretion, supra note 102 , at $62-63$.

130. See id. at 62 .

131. See id. 
ness. ${ }^{132}$ Accordingly, the optimal system in the European context might be one which is politically independent but nonetheless politically responsive. This framework would allow the competition authorities to inake decisions without undue pressure from lobbyists while knowing that an unpopular decision will exact a political price.

2. The French System. While the German system has overemphasized an independence which seems hermetically sealed froin popular opinion, soine of the southern European Member States have industrial and economic policies that resemble those of France, ${ }^{133}$ which err on the side of excessive government involveinent in the name of the people. The French tradition of dirigisme, or direct state involvement im economic markets, elevates concerns such as unemployment above free competition. ${ }^{134}$ Indeed, in France, mergers involving government-regulated enterprises are exempt from antitrust inquiry. ${ }^{135}$

While France's competition laws date back centuries, modern notions of free competition were not included until after World War $I I{ }^{136}$ Even these laws, however, were not effectively administered until the late Seventies and early Eighties. ${ }^{137}$ In 1977, la Commission de la Concurrence ("The Competition Commission") was founded as the administrative body charged with investigating coinpetition law violations. ${ }^{138}$ The Competition Commission, an institution independent of the governmental ministry, ${ }^{139}$ was fashioned after the EC system. The ordonnance du ler décembre 1986 increased the French commitment to competition policy by adopting many of the provisions of Articles 85 and 86. ${ }^{140}$ This amendinent also established Le Conseil de la Concurrence ("The Competition Council") in place of the Competition Comunission. ${ }^{141}$

132. See id. at $62-63$.

133. See id. at 54.

134. See id.

135. See Roger A. Boner \& REINAID KRUEger, THE Basics of ANTITRUST POLICY: A REVIEW OF TEN NATIONS AND THE EUROPEAN COMMUNITIES 33 (World Bank Technical Paper No. 160, 1991).

136. See id. at 32 .

137. See id. at 32-33.

138. See id. at 32.

139. See id.

140. See id. at 33.

141. See Gabriel Gutry, Prattque du Drott des AfFaires [Practicing Busi- 
The Council is composed of seven former members of the government or judiciary, four experts in economics, competition and commerce and five executives or workers from major industrial sectors. ${ }^{142}$ This ensures the Competition Council an independent board which is nonetheless tied to the government via the Economic Minister's power to appoint the members. ${ }^{143}$ However, consistent with French industrial policy, in practice hittle power of decision has been bestowed upon the Competition Council, ${ }^{144}$ and most decisions are still taken by the Cabinet or by the Minister of Economics. ${ }^{145}$

Isolating independent agencies from policymaking power is consistent with the traditional French belief that the government should monitor the nuarket and intervene when it finds necessary in order to iniprove market conditions. This approacl is also consistent with France's traditionally suspicious view of the ability of the free market to regulate itself. Accordingly, the French view European competition law with a much inore critical eye and are considerably less enthusiastic about doling out additional economic powers to the Union. ${ }^{146}$ Therefore, the French competition systein, as one inolded after the European system and then perverted in order to promote government intervention, is wholly inappropriate as a nodel for a new independent body which should epitomize free market economics and a belief in the ability of the inarket to correct itself in situations of natural competition.

3. The British System. The other sophisticated and widely respected competition regime in Europe is the British system. This system, while containing some notable differences, is based upon American antitrust traditions. ${ }^{147}$ The Director General of Fair Trading (DGFT) occupies the focal position in British competition

\footnotetext{
NESS LAW] 289 (6th ed. 1994).

142. See id. at 290.

143. See id.

144. See BONER \& KRUEGER, supra note 135, at 33-34.

145. See Henri Aujec, An Introduction to French Industrial Policy, in FRENCH INDUS-

TRIAL POLICY 13 (William James Adams \& Christian Stoffaës eds., 1986).

146. See Ehlermann, supra note 100, at 474-75.

147. See NICK GARDNER, A GUIDE TO UNITED KINGDOM AND EUROPEAN COMMUNITY COMPETIMON POLICY 18 (1990). When the UK was establishing its competition system, the United States already had fifty years of experience in antitrust enforcement. Id.
} 
law. ${ }^{148} \mathrm{He}$ carries out numerous important functions, including drafting an Annual Report which often directs reform of the domestic system. ${ }^{149}$ With limited exceptions, the DGFT and his staff at the Office of Fair Trading (OFT) perform all monitoring functions and initiate investigations. ${ }^{150}$ The OFT gathers information about monopolies and mergers, acts as the British competition authority internationally, works with the Commission on EU matters, advises the Secretary of State in merger regulation, and reports to the Secretary of the State on the status of competition in the UK. ${ }^{151}$ Even though the OFT is ostensibly an apolitical institution, due to the wide range of areas in which it has competence, the OFT quite often plays a greater role in competition matters than its advisory status might suggest. ${ }^{152}$ The OFT enjoys considerable independence from the Secretary of State. ${ }^{153}$ Political review ultimately rests with the Secretary of State, while most judicial appeals in competition are sent to the Restrictive Practices Court, which is equivalent in status to a High Court. 154

There is another competition authority which is given great powers of investigation in the areas of monopolies and mergers under British competition law. This institution, the Monopolies and Mergers Commission (MMC), has no original jurisdiction, but is given the power to conduct investigations under a number of British laws. ${ }^{155}$ The MMC also has a narrow shice of appellate jurisdiction under the 1990 Broadcasting Act, ${ }^{156}$ but it functions al-

148. See id. at $54-55$.

149. See RICHARD WHISH, COMPETITION LAW 21 (3d ed. 1993).

150. See MERKIN \& WILlIAMS, supra note 2 , at 17.

151. See GARDNER, supra note 147 , at 54-55.

152. See MERKIN \& WILliams, supra note 2, at 19.

153. The Secretary of State has the power to overrule the OFT in the areas of competition investigation, merger references and monopoly references. See GARDNER, supra note 147, at 58. Additionally, of course, the OFT and the DGFT only serve in an advisory capacity for policy determination; the final policy decisions lie with the Secretary of State. See id. Historically, however, the DGFT has been very influential in determining competition policy. See id.

154. See MERKIN \& WILliAMS, supra note 2, at 22.

155. See WHISH, supra note 149, at 23 (stating that the MMC "has important functions under the Fair Trading Act 1973, the Competition Act 1980, the Telecommunications Act 1984, the Airports Act 1986, the Gas Act 1986, the Electricity Act 1989, the Broadcasting Act 1990 and the Water Industry Act 1991").

156. Broadcasting Act, 1990, ch. 42 (Eng.). 
most exclusively as an advisory body. ${ }^{157}$ The MMC is comprised of full-time civil servants who are drawn from industry, the professions, academia, trade unions and retail busmesses; ${ }^{158}$ however, while the MMC is an independent institution, it is technically subordinate to the DGFT, who is officially charged with acquiring and reviewing all information on mergers and monopolies in the UK. ${ }^{159}$ In practice, the MMC's opinions have proven to be accurate and influential despite its lack of enforceinent powers. ${ }^{160}$

In the European context, the British system displays many of the same attributes and faults as the German systein. The considerable independence of the OFT is akin to the autonomy enjoyed by the BktAmt. ${ }^{161}$ However, the relationship between the Secretary of State and the OFT differs considerably from that between the FME and the BktAmt. The German relationship is based on countervailing power, ${ }^{162}$ while its British counterpart tends to be based on a desire for consensus. ${ }^{163}$ While the German FME rarely overturns a BktAmt decision because it fears what the public reaction might be, ${ }^{164}$ the Secretary of State consistently affirms the OFT's position, normally, as a result of the coordination between the two entities, not as a result of a fear of possible public criticisin. The practical difference is that while the FME is shielded from direct BktAmt influence in policymaking, the OFT heavily influences the Secretary of State. This, however, can be viewed as a weakness of the English system, because in order to preserve imdependence, it would be advantageous to insulate the OFT from policy influence.

Other flaws in the British systein would need to be ounitted from an ECO inodeled on the English system. One flaw is that the DGFT has a monopoly on inany of the decisions it makes. ${ }^{165}$ This problem, which is endernic in DG-IV as well, manifests itself

157. See Whish, supra note 149, at 28.

158. See MERKIN \& WILLIAMS, supra note 2 , at 21.

159. See WHISH, supra note 149 , at 27.

160. See id. at 28.

161. See supra text accompanying notes 107-110.

162. See supra note 112 and accompanying text.

163. See GARDNER, supra note 147, at 57-58 (noting that the Director General enjoys almost complete independence and that the Secretary of State rarely uses its veto power or entirely rejects the advice of the Director General).

164. See supra notes 125-26 and accompanying text.

165. See WHIsH, supra note 149 , at 759 . 
in the ability of the OFT to play investigator, prosecutor, judge and jury in the same case. ${ }^{166}$ In order to rectify this problem, a reform was proposed under which official political review would reinain with the Secretary of State, the final decision to take a case would lie with a body independent of the DGFT, and judicial review, including the ability to impose fines, would rest with the Court. ${ }^{167}$

The European systein also imight include an effective advisory body on inonopolies and inergers, akin to the MMC. Removing investigation of these issues froin DG-IV would greatly benefit the Commission. However, a number of problems would have to be addressed before such an institution could be established. One problein with this reform is that it adds an institution to a system already burdened by too many institutions. ${ }^{168}$ The European competition system lacks resources, ${ }^{169}$ and supporting new institutions would be difficult. Furthermore, the introduction of a body similar to the MMC might create an institutional framework which is too complex and inefficient. The use of an independent administrative procedure for investigation lias proven to be slow and costly $^{170}$ because the MMC's procedures are intrusive to companies under investigation, its investigations are extreniely lengtliy and its rationale for investigation is often couched in vague terms. ${ }^{171}$ Finally, the MMC also plays the roles of botli investigator and judge, and thus lacks transparency. ${ }^{172}$ In sum, the MMC, while being a respected and useful institution in the United King-

166. See id. at 733 .

167. See id. The institutional difference between the modified German system and this modified British system is critical. The proposal suggested to modify the German system suggests that final decisions would rest with the BktAmt. The British system would be modified so that the power of final decision would be removed to an independent body. The difference between these proposals might best be explained by the differing levels of influence the "effective" body has in the political review process in its domestic system. In the German system, the BktAmt has little say concerning political review. See supra notes 109-110 and accompanying text. In the UK, the OFT is very influential in these decisions. See supra note 152 and accompanying text. Accordingly, it would be necessary to create an additional barrier (e.g., removing the power of final decision) to the OFT reigning with no political responsibility for its decisions.

168. See WHISH, supra note 149 , at 26.

169. See, e.g., Gerber, supra note 36, at 143; GoYDER, supra note 3, at 489; Ehlermann, supra note 100 , at 479 .

170. See MERKIN \& WILLIAMS, supra note 2, at 21-22.

171. See id.

172. See id. at 22 . 
dom, would have to be adapted considerably before it could be an effective model upon which to base European reform. Much of its present success derives from the quahity of its work and from the relationship it shares with the OFT. These elements are countryspecific, and the prospect that such characteristics would arise in the European context is not significant enough to outweigh the additional economic and institutional burden created by this authority, unless its procedures are more efficient than those employed by the overburdened DG-IV.

4. Conclusion: Member States' Systems. There are considerable lessons to be taken from the German and Enghish systems. Further, the competition regimes of the EU Member States have the advantage of being administered and operated within the European Umion. While the economic traditions of the Member States vary widely, ${ }^{173}$ many intangible similarities originate in the common European experience. These intangibles, although difficult to account for in a comparative analysis, should not be ignored. Additionally, there are advantages in the Commission's ability to employ the Member State nationals who administered the domestic systems as the personnel to implement the new authority. The benefits which could be derived from the collective experiences of such administrators might be invaluable. These factors are especially important when considering the additional cultural leap which would have to be braved in order to implement a system based upon another alternative-the American antitrust tradition.

\section{The American System}

The Umited States was the first industrial nation to institute an effective antitrust system with sweeping application. ${ }^{174}$ Due to its maturity and the strong American sentiment against restraints on free competition, this system has remained unique in its broad scope as well as in its rigorous enforcement. ${ }^{175}$ The deep-seated sentiment against restramts on free competition has its historical

173. See HARRISON, supra note 4, at 202-203.

174. The Sherman Act was passed in 1890, the Clayton Act and the Federal Trade Commission Act in 1914. These three acts are the statutory fundamentals of American antitrust enforcement. See A. D. NEALE \& D. G. GOYDER, THE ANTITRUST LAWS OF THE UNITED STATES OF AMERICA $3-4$ (1980).

175. See id. at 1 . 
roots in America's post-Civil War industrial boom. ${ }^{176}$ Pressure for reform led to the Sherman Act of $1890 .{ }^{177}$ Enforcement of the Sherman Act was delegated to the Department of Justice and to the courts, but the details of this enforcement mechanism were not given. By the turn of the century, it was clear that the simple machinery in the Sherman Act was inadequate to properly battle the complicated anticoinpetitive regimes which had established themselves in the United States. ${ }^{178}$ Furthermore, in the 1911 Supreme Court decisions in Standard Oil ${ }^{179}$ and American Tobac$c o,{ }^{180}$ the so-called judicial "rule of reason" was introduced into American antitrust jurisprudence. ${ }^{181}$ This new rule threatened to introduce serious problems of uncertainty into the system. ${ }^{182}$ Ac-

176. See Phillip AREeda \& Louis Kaplow, ANTITRUST ANALYSIS $48-50$ (1988). With rapid economic growth came inequities between the agrarian and the manufacturer, between small and big business. See id. Farmers received low prices on agricultural products while paying high prices on farm machinery imposed by monopolies im major manufacturing industries while the industrialists expanded their empires by buying out and destroying smaller, competing businesses. See id. at 48-49. Under these circumstances, it was clear that America was gripped by unfair, yet prevalent, anticompetitive behavior.

Concerns about concentration of economic power date back even farther in American history:

Antitrust must be understood as the political judgment of a nation whose leaders had always shown a keen awareness of the economic foundations of politics. In this respect, [the enactinent of antitrust laws] was simply another manifestation of an enduring Anerican suspicion of concentrated power. Froin the preRevolutionary tracts through the Declaration of Independence and The Federalist to the writings of the states' rights advocates, and beyond the Civil War into the era of the antimonopoly writers and the Populists, there had been a perennial quest for a way of dividing, diffusing, and checking power and preventing its exercise by a single interest or by a consolidated group of interests at a single center.

RICHARD HOFSTADIER, What Happened to the Antitrust Movement?, in THE PARANOID STYLE IN AMERICAN POLITICS AND OTHER ESSAYS 188, 205 (1965).

177. The Sherman Act contains two main provisions: Section 1 makes "combinations . . . in restraint of trade" illegal; Section 2 prohibits monopolization or attempts to monopolize. 15 U.S.C. $\S \S 1-2$ (1994). The wording einphasized the congressional intent to simply codify what was considered common law notions of competition. See 21 CoNo. REC. 2, 456 (1890). While the Act is sometimes criticized for its vague language, it is widely believed that the promulgation of the Act was simply a legislative cominand to the judiciary to develop this area of the common law. See AREEDA \& KAPLOW, supra note 176 , at 5-6.

178. See Robert E. Cushman, The INDEPENDENT REgulatory COMMissions 177-78 (1941); SUSAN WAGNER, THE FEDERAL TRADE COMMISSION 8-10 (1971).

179. Standard Oil v. United States, 221 U.S. 1 (1911).

180. United States v. American Tobacco Co., 221 U.S. 106 (1911).

181. The "rule of reason" doctrine stated that not all restraints of trade were prohibited under the Sherman Act, but only those which were found to be "unreasonable." See Standard Oil, 221 U.S. at 62; American Tobacco, 221 U.S. at 179.

182. The major concerns, arbitrary enforcement and lack of standards for businessmen 
cordingly, calls to create a federal commission on unfair trade emerged, and in 1914 two new antitrust acts were passed. ${ }^{183}$ The Federal Trade Commission Act $^{184}$ established the Federal Trade Commission (FTC) ${ }^{185}$ and created FTC jurisdiction over "unfair methods of competition." 186 The Clayton Act expanded antitrust jurisdiction by delineating four specific practices which were deemed illegal. ${ }^{187}$

The FTC was intended to be an independent administrative agency staffed by non-partisans who were thoroughly experienced im the intricacies of competition. ${ }^{188}$ Two claracteristics decisively distinguish the FTC from other nations' authorities: the dynamics of its independence and its overlapping autlority with the Department of Justice. The independence of the agency was an assumed characteristic during its creation; "[t]he two ideas, a commission and independence for the commission, were inextricably bound together."189 While independent regulatory agencies were not unusual im the United States, ${ }^{190}$ the FTC was the first agency that

to judge whether a venture was illegal under the Sherman Act, created doubt that the Department of Justice's enforcement of the Act was sufficient to combat monopoly power. See Alan H. Silberman et al., The FTC as an Antitrust Enforcement Agency: The Role of Section 5 of the FTC Act in Antitrust, 1 A.B.A. SEC. OF ANTTTRUST L. 3, 7-11 (1981).

183. See WAGNER, supra note 178 , at 14-18.

184. 15 U.S.C. $\S \S 41-58$ (1994).

185. Id. § 41 .

186. WAGNER, supra note 178 , at 17 . The FTC Act created a broad prohibition against "unfair methods of competition" and provided for the agency to delineate standards of competition under this definition. 15 U.S.C. $\S \S 41-58$. The FTC Act has been amended numerous times since its proinulgation. For a full list of amendments and a brief discussion of the most significant, see PETER C. WARD, FEDERAL TRADE COMMISSION: LAW, PRACTICE AND PROCEDURE \& 1.03 n.1, § 1.03[1]-[7] (perm. ed. rev. vol. 1996).

187. The Clayton Act deemed the following to be illegal: 1) price discrimination; 2) exclusive-dealing and tying contracts; 3) acquisitions of competing companies; and 4) interlocking directorates. See 15 U.S.C. \$§ 12-27.

188. See WAGNER, supra note 178 , at 19 . The independent agency would be more accurate, because of its expertise in the field, and would work more expeditiously by passing applications through an administrative, as opposed to judicial, process. See Silberman, supra note 182 , at 20.

189. CUSHMAN, supra note 178 , at 188.

190. For example, the Interstate Commerce Commission (ICC) was an independent regulatory agency established in 1887. See CARL MCFARLAND, JUDICLAL CONTROL OF THE FEDERAL TRADE COMMISSION AND THE INTERSTATE COMMERCE COMMISSION 102 (1933). In the congressional debates on whether to establish an independent commission on interstate commerce, Speaker Covington explamed, 
was not charged with regulating a particular industry, but rather was to regulate the myriad American markets and businesses which were not otherwise subject to federal regulation. ${ }^{191}$

The FTC is also unique in that it shares responsibility for enforcing the antitrust laws with another governmental entity, the Departinent of Justice Antitrust Division (DOJ). ${ }^{192}$ There has been considerable discussion as to the effectiveness of the current system's use of dual federal antitrust enforcement. ${ }^{193}$ Jurisdiction is divided such that the DOJ exclusively enforces the Sherman Act, the FTC exclusively enforces the FTC Act, and both agencies enforce the Clayton Act. ${ }^{194}$ Many questions arise, however, as to the most appropriate statute under which to bring a suit. ${ }^{195}$ This problem is effectively dealt with by a process of notification and clearance. ${ }^{196}$ Further, there are well-established haison arrange-

[T] he great value to the American people of the Interstate Commerce Commission has been largely because of its independent power and authority. The dignity of the proposed commission and the respect in which its performance of its duties will be held by the people will also be largely because of its independent power and authority. Therefore the bill removes entirely from the control of the President and the Secretary of Commerce the investigations conducted and the information acquired by the commission.

51 Cong. Rec. 8,842 (1914). However, some expressed a divergent view. See 51 Cono. REC. 12,742 (1914) (comments by Sen. Cummins discussing the commission's purely executive or administrative nature as opposed to the legislative-administrative structure of the Interstate Commerce Commission).

191. See WAGNER, supra note 178 , at 36 .

192. See id. at 37.

193. See Donald I. Baker, Dual Enforcement: Coordination, Competition or Confusion?, NAT'L L.J., Dec. 18, 1978 at 26; Miles W. Kirkpartick et al., Report of the American Bar Association Section of Antitrust Law Special Committee to Study the Role of the Federal Trade Commission, 58 ANTTrRUST L.J. 43, 113-119 (1989) [hereinafter ABA Report on FTC]; Study on Federal Regulation Volume 5, 1977: Hearings on S. 402-33 Before the Antitrust Sub-Comm. of the Senate Judiciary Comm., 95th Cong., intro. at 11 (1977) [hereiuafter Senate Hearings on Federal Regulation). See generally EDWARD F. COX ET AL., "THE NADER REPORT" ON THE FEDERAL TRADE COMMISSION 57-69 (1969) (discussing problems that have arisen under the dual enforcement regime).

194. See WAGNER, supra note 178 , at $17-18$; NEALE \& GOYDER, supra note 174 , at 3-4.

195. The FTC has used its power to enjoin "unfair and deceptive" practices to reach what the DOJ might consider to be monopolistic practices. See Baker, supra note 215, at 26. This has resulted in both agencies challenging the same offense under different statutes; because the Supreme Court held in FTC v. Cement Institute that the statutes are "cumulative remedies" a suit brought by one agency does not bar another suit from being brought by the other. See 333 U.S. 683,694 (1948).

196. See David L. Roll et al., The FTC as an Antitrust Enforcement Agency: Its Structure, Powers and Procedures, 2 A.B.A. SEC. ANTTTRUST L. 16 (1981). When one agency's staff proposes to open a particular investigation, it will provide notice to the other agency and such notification will generally result in "clearance" by the latter agency. See 
ments between the agencies, and accordingly there has historically been little conflict over jurisdiction. ${ }^{197}$

While jurisdictional disputes are rarely a public problem, the duplication of duties between the FTC and the DOJ is often criticized as mefficient. Most supporters of umtary enforcement cite additional costs and uncertainty as the most forceful arguments for American antitrust reform. ${ }^{198}$ While it might appear that the duplication of duties could impose additional costs, because the agencies' rarely investigate the same case and share information, few additional costs actually accrue. Additionally, the costs of reorganizing the current system might well outweigh any added efficiency. Moreover, the administrative monster which would arise from combining the two agencies miglit well "look[] too mucl like a bureaucratic Penn Central."199 Admittedly, the uncertainties which arise because businesspersons need to heed the positions of both agencies before evaluating a venture might be substantial; however, this simply forces ventures to err on the side of avoiding anticompetitive action. ${ }^{200}$

On the other hand, there are numerous advantages to dual enforcement. As the DOJ is a division of the executive branch, ${ }^{201}$ it has been subject to control by the differmg administrations. It is headed by the Assistant Attorney General, who is a presidential appoimtee; thus, her policies are usually influenced by the executive branch. ${ }^{202}$ In contrast, the FTC is most heavily influenced by Congress. ${ }^{203}$ Therefore, no government branch has a monopoly on antitrust enforcement or policy.

The FTC's independence is central to its success as a regulatory agency. A distrust of politics led the founders of the FTC to fear that decisions would be influenced by pohtical consider-

Baker, supra note 193, at 26-27. Any disputes are sent through the liaison and up the chain of command until they can be resolved. See id.

197. See NEALE \& GOYDER, supra note 174 , at 373 . There is a designated FTC liaison officer who regularly communicates with the DOJ in order to avoid disputes or duplication. Also, certain industries have been informally allotted between the agencies. See id.; Baker, supra note 193, at 27.

198. See Baker, supra note 193, at 27; ABA Report on FTC, supra note 193, at 120.

199. Baker, supra note 193 , at 27.

200. See id.

201. See NEALE \& GOYDER, supra note 174, at 373.

202. The DOJ is often motivated by public policy as well as the Executive's concerns.

See id. at 373-74.

203. See infra notes $210-17$ and accompanying text. 
ations. ${ }^{204}$ Accordingly, the FTC has been as removed from the direct influence of the executive branch as Congress could manage. ${ }^{205}$ The President exerts his influence through only two devices. ${ }^{206}$ One is the President's ability to review the budget. ${ }^{207}$ The second device, which has been more effective for the President, is his power to appoint the FTC Commissioners and Chairman. ${ }^{208}$ However, as there are few chances for appointment and as the President's power to remove appointees has been strictly curtailed by the Supreme Court, ${ }^{209}$ the FTC has generally operated free of political pressure from the varying executive administrations.

Congressional influence, however, is considerably stronger. ${ }^{210}$ The most significant means by which Congress can exert its power over the FTC is by its direct control over the FTC's budget. ${ }^{211}$ However, while Congress' ability to hold its budgetary club over the FTC's head has resulted in some political extortion, ${ }^{212}$ the

204. See 51 CONG. REC. 8,857 (1914) (statement of Sen. Morgan) ("It is unsafe for an administration in power, an administrative officer representing a great political party, to hold the power of life and death over the great business interests of this country .... Whatever we do in regulating business should be reinoved as far as possible from political influence.").

205. See Senate Hearings on Federal Regulation, supra note 193, at 30-32.

206. See WAGNER, supra note 199 , at 212.

207. See id. at 213.

208. See Senate Hearings on Federal Regulation, supra note 193, at 41.

209. See Humphrey's Executor v. United States, 295 U.S. 602 (1935) (holding that the President has no constitutional power to remove Commissioners other than for inefficiency, neglect of duty, or malfeasance in office).

210. See Senate Hearings on Federal Regulation, supra note 193, at 30. In 1971, the Ash Council affirmed the propriety of Congress' role in the FTC, asserting that the congressional duty to regulate interstate commerce under Article II of the Constitution was a proper basis for federal regulation. See id. at 31 .

211. The House and Senate Appropriations Committees, acting on requests from the President, are charged with the appropriation of funds to the independent regulatory agencies. See Senate Hearings on Federal Regulation, supra note 193, at 40. By controlling the purse strings, Congress can exert considerable influence over independent agencies such as the FTC. See id.

212. For example, the precipitous decline in antitrust activity associated with the Reagan administration was due in part to congressional backlash against the FTC's activism in the 1970's. See Marc Allen Eisner, Bureaucratic Professionalization and the Limits of the Political Control Thesis: The Case of the Federal Trade Commission, GovernANCE: INT'L J. POL'Y AND ADMN., Apr. 1993, at 127, 135-36, 139. The merger between LTV, a diversifled aerospace coinpany, and Lykes Corp., a conglomerate with considerable steel interests, was reviewed by both agencies, an act contrary to usual practice, after Senator Edward M. Kennedy insisted that the DOJ's application of the "failing company exception" was inaccurate. For a discussion of the political dynamics, see generally Baker, supra note 193. 
FTC has managed to forge its own policy determinations. ${ }^{213}$ In order to keep the FTC's conduct in check, Congress once considered a "legislative veto" which would allow either house of Congress to nullify any future action taken by the FTC. ${ }^{214}$ While this policy probably is not constitutional, ${ }^{215}$ Congress still retains the power to delay FTC action for a specified period. ${ }^{216}$ Moreover, members of Congress, as U.S. citizens, have the right to suggest litigation, propose rules, and provide their opinions. ${ }^{217}$ Fmally, certain members of Congress, particularly committee chairmen, exert influence over the institutional development of the FTC.

The final check on the FTC is the judiciary. It is often the most effective check, because it is the only branch which can formally review and overturn FTC decisions. ${ }^{218}$ In comparison with

Congress effectuates its oversight role through the Office of Management and Budget (OMB). The OMB was created as a nonpartisan agency of budgetary experts and specialists in financial policy. See Senate Hearings on Federal Regulation, supra note 193, at 43. In referring to the agency's role vis-à-vis the executive and the legislature, the first director of the Bureau of the Budget (the direct predecessor to the OMB) commented:

We have nothing to do with policy. Much as we love the President, if Congress, in its omnipotence over appropriations and in accordance with its autlority over policy, passed a law that garbage should be put on the White House steps, it would be our regrettable duty, as a bureau, in an impartial nonpolitical and nonpartisan way to advise the Executive and Congress as to how the largest amount of garbage could be spread in the most expeditious and economical manner.

Gary Bombardier, The Managerial Function of OMB: Intergovernmental Relations as a Test Case, 23 PUB. POL'Y 317, 320 (1975) (quoting Charles G. Dawes) (citations omitted).

However, the OMB has been accused of being an enthusiast of the executive and has not been afraid to administer its duties to the detriment of the FTC. It has denied as many as 200 staff positions in a single year to the FTC. See Senate Hearings on Federal Regulation, supra note 193, at 44, 47.

213. The rhetoric on the House fioor in 1980 strongly suggested that Congress was not able to direct FTC policy to its pleasure. See Eisner, supra note 212, at 135. A good example of the FTC's defiance of Congress in order to implement a plan which has proven to be immensely popular, and now supported by Congress, is the FTC's trade policy conference work. See CUSHMAN, supra note 178, at 220-22.

214. See Eisner, supra note 212, at 135.

215. See INS v. Chadlia, 462 U.S. 919,959 (1983) (holding that a one-House veto is legislative in character and does not fall within the narrowly defined circumstances in which either House of Congress may act outside of its prescribed bicameral legislative role).

216. See Senate Hearings on Federal Regulation, supra note 193, at 41.

217. $A B A$ Report on FTC, supra note 193, at 109.

218. See generally MCFARLAND, supra note 190, at $42-43$ (stating that the scope of the commission's powers depends upon the action of the commission as limited by the courts). 
the other branches, its role is straightforward and has provided effective control over the FTC. ${ }^{219}$

The FTC is thus placed in a delicate position; it inust balance its relations with all of the different agencies and government branches which interact with it, and it must balance many different interests and policies. ${ }^{220}$ While this leads to an admittedly convoluted systein, most commentators agree that the system does not warrant significant reform. ${ }^{221}$ The question remaims, loowever, whether such a system would serve as an effective model for an independent agency in the European Umion.

Despite the concern that the American legal tradition is too foreign to the European Union's legal tradition to effectively serve as a model for EU institutions, ${ }^{222}$ a closer analysis indicates that some features of the American systein may be adaptable to European needs. The fundamental primciples upon which the European competition regime rests are similar to those embraced by American antitrust laws. ${ }^{223}$ This similarity is partially due to the fact that the European competition regime was influenced, and in some ways patterned after, the American antitrust system. ${ }^{224}$ American thought and literature also has continued to influence European competition policy. ${ }^{223}$ Further convergence is desirable and might be fostered by parallel institutions and ideals.

In several aspects, the American systein inay be a better inodel for European competition than the Meinber States' systems. For instance, the American antitrust regime is fully implemented in a

219. See generally id. at $43-90$ (providing a chronological summary of judicial decisions affecting the FTC).

220. See WAGNER, supra note 178, at 202.

221. See generally $A B A$ Report on FTC, supra note 193, at 55-56 (noting that the system of dual enforcement has wide support and likely will not be reformed); Senate Hearings on Federal Regulation, supra note 193, at 80 (surmising that the independent status of the regulatory agencies is effectively isolated from politics and should be continued); Baker, supra note 193, at 27 ("I do not find the case for or against dual enforcement compelling. But because it is in place, and because making changes imposes new costs, I am inclined to leave it the way it is absent a coinpelling showing.").

222. For an overview of the problems involved with using the American system as a model for the EEC, see FEJ $\emptyset$, supra note 1, at 9-12.

223. See id. at 12 (" $[B]$ oth the USA and the EEC rest on common and fundamental interest in and respect for the maintenance of a free, fair, and competitive market system.") (emphasis omitted).

224. See id. at 12-13.

225. See id. at 13-17. 
federalized system. Some Member States, such as Germany and Belgium, do have federal legal systems; however, the division between federal and state jurisdiction is of primary importance only im the American and EU legal regimes. Thus, the American system addresses many of the same problems that plague the EU regime, such as pohticalization, transparency and subsidiarity. In many ways, a body modeled after the FTC would be poised to achieve many of Europe's goals for competition reform.

For example, the FTC was established in order to isolate it from politics. ${ }^{226}$ While its close ties with Congress do not always leave it free of the political whims of interest groups, lobbyists and politicians, ${ }^{227}$ the FTC has nonetheless been relatively effective in isolating itself from the pohitical clout of the executive branch. Similarly, a mam impetus for European competition reform is a desire to remove it from the direct control of the Commission. However, the Commission is a governmental body entirely foreign to the American system. This hybrid governmental entity performs tasks associated with each of the branches of the U.S. governinent. ${ }^{223}$ Therefore, attempts to evaluate whether an FTC-like institution would be effectively independent from the Commission must be based on general policy considerations. For instance, it is very difficult to determine if the ECO could be as effectively shielded from Commission intervention as the FTC is from intervention by the executive branch. Regardless, due to their similar functions and fundamental ideals, its seeins that the FTC could serve as an effective general model for a European ECO.

There are other characteristics of the U.S. system which lend themselves to implementation in the EU because, in many respects, the political climate in Brussels is more similar to that in Washington than to that in any of the Meinber States' capitals. This similarity arises from the fact that both the U.S. system and the EU system are federal systems. In systems which are based upon protecting the individual sovereignty of the states, it should be expected that there is not a unitary ideology, but a systein based upon the promotion of various specific interests. It is therefore not surprising that Washington and Brussels both lack deep ideological roots. ${ }^{229}$ For example, lobbying efforts im both Wash-

226. See supra notes $188-91$ and accompanying text.

227. See Eisner, supra note 212 , at $135-37$.

228. See supra note 18 and accompanying text.

229. See Claus-Dieter Ehlermann, Comments by Claus-Dieter Ehlermann, in CoNSTITU- 
ington and Brussels are similar because they are based on special interests. ${ }^{230}$ In contrast, lobbying in European Member States tends to be ideological. ${ }^{231}$ Therefore, the manner in which the FTC and DOJ operate to avoid undue pressure from lobbyists will be better adapted to the federalized EU system than that of any of the Member States' competition institutions.

Like the Europeans, Americans have long been concerned with political transparency. However, the American system has dealt with this problem very differently than the European system has. The American system has instituted statutory procedures which strongly favor public exposure of FTC and DOJ decisions. ${ }^{232}$ As these procedures are the result of statutory interpretation, common law precedent and policy formulation, their advantages eventually could be rendered im most institutional frameworks. However, this tradition of public exposure has left a long history, tomes of statutes and many cases, ${ }^{233}$ and it might be assumed that while there is effective transparency in the U.S. systeen, much of its history is specific to American jurisprudence and therefore would be difficult to duphicate in the European system. It certainly would take considerable time for Europe to create its own effective policy; however, the advantage of the American tradition of public exposure is that the U.S. experience is welldocumented and accessible to the Europeans. With thoughtful consideration of these experiences, and after taking into account cultural differences, the EU could learn from the American model of transparency.

While the cultural gap between the U.S. and Europe is surmountable, there are elements-such as the political relationship between state and federal entities-which are too distinct to be effectively transposed onto the European system. The American perception of the relationship between the states and the federal government has fundamentally affected the American approach to subsidiarity. Economically, socially, and culturally, American society is far more integrated than that of Europe. ${ }^{234}$ In the EU, the

TIONAL DIMENSIONS OF EUROPEAN ECONOMIC INTEGRATION 95, 95 (Francis Snyder, ed., 1996).

230. See id.

231. See id.

232. See WAGNER, supra note 178 , at 202-08; WARD, supra note $186, \S 2.11$.

233. See, e.g., Freedom of Information Act, 5 U.S.C. $\$ 552$ (1994); FTC Miscellaneous Rules, C.F.R $\S \S 4.9$ (b), 4.11 (1996).

234. See John T. Lang, 17 COMMON MKT. L. REV. 457, 458 (1980) (reviewing BARRY 
Member States often vie for their differing national policies despite the supranational character of the Union. ${ }^{235}$ This subversion of supranationality in the interests of national policy results in a less honiogenous economic policy than that found in the U.S. ${ }^{236}$ In the U.S., federal jurisdiction has been construed broadly in order to niaximize federal authority. In contrast, the European Court of Justice has strictly narrowed the interpretation of European Union jurisdiction. ${ }^{237}$ Therefore, while the U.S. systen1 cannot offer any lessons as to how to unprove subsidiarity ${ }^{238}$ it does serve as a successful inodel of effective cooperation, where preeniption stirs little conflict and where there are little doubts as to the limits of state jurisdiction. ${ }^{239}$

E. HaWk, United STates, Common Market and International ANTitrust: A Comparative GUIDE (1979)).

235. See FEJ $\varnothing$, supra note 1 , at 9-10.

236. See id. at 10.

237. For example, both Articles 85 and 86 recognize that actions may affect "trade between Member States," EEC Treaty, supra note 4, arts. 85 \& 86, 298 U.N.T.S. at 47-48, and sections 1 and 2 of the Sherman Act prohibit "restraints among the several States," 15 U.S.C.A. §§ 1, 2 (West Supp. 1996). Arguably, the European language may promote a wider interpretation of federal (EU) jurisdiction. In practice, however, the European Court of Justice has stated that the aim of this language is to himit European jurisdiction, and the boundaries of European jurisdiction have been contentiously hitigated. In contrast, the jurisdictional requirement of the Sherman Act has rarely been tested in court. See FEJØ, supra note 1, at 11.

European jurisdiction has also been limited by institutions other than the Court. See, e.g., Dan Goyder, The Implementation of the EC Merger Regulation: New Wine in Old Bottles, 45 CURRENT Legal Problems 117, 122-23 (R.W. Rideout \& B.A. Hepple eds., 1992). Under the terms of Article 1 of the Merger Regulation, the Commission only takes jurisdiction in cases with a world turnover of at least ECU 5 billion (approximately $\$ 6.4$ billion) and an aggregate Community-wide turnover of at least ECU 250 million (approximately $\$ 320$ million). See id. Therefore, only the very largest mergers fall within Union jurisdiction. See id. The Commission has expressed considerable dissatisfaction with the narrowness of this jurisdiction, and will likely request to have these thresholds lowered at the next review of the Merger Regulation. See Lionel Barber, German with Plan for EC Glasnost, FIN. TIMES, Mar. 2, 1993, at 2.

238. Indeed, it has been suggested that perhaps the U.S. could take a page out of the European book in this area. See Barry E. Hawk \& James D. Veltrop, Dual Antitrust Enforcement in the United States: Positive or Negative Lessons for the European Community, in PROCEDURE AND ENFORCEMENT IN E.C. AND U.S. COMPETTTION LAW 21, 31 (Piet Jan Slot \& Alison McDonnell eds., 1993).

239. See id. 
While the European Union was originally envisioned as a "United States of Europe" ${ }^{240}$ in which the many European nations could coexist peacefully, the analogy to the U.S. must be viewed as largely symbolic. ${ }^{241}$ The enormous cultural, economic, and political differences among Europe's Meniber States create a nuch less integrated society than that in the United States. ${ }^{242}$ Thus, while the FTC is highly independent, it is not clear that it serves as an ideal noodel for a European agency. This slould not, however, suggest that an evaluation of the FTC model and the American systen in general is worthless in European conpetition reform. To the contrary, the simple fact that the United States has the nost sophisticated and extensive antitrust system demonstrates the importance of its evaluation. Further, as noted, this sophisticated systen offers several fresh solutions to nrany of the EU's problems. While there are cultural and political differences between the continents, it seems that in this increasingly international world, thoughtful application of U.S. principles in the EU regime could be effective. Even entirely differing political, historical, cultural and legal systems warrant comparison. Jens Fejø posits that

comparison may also shed hight upon some essential points. If the comparison is made between spheres of law which have not yet assumed their permanent form, it may serve as guidance in the developinent of the law, provided that the comparison is inade with great care. And even though a state of law may seem permanent, a coinparison inay lead to new thinking and reappraisal. It may also widen the perspective and raise the judicial level. ${ }^{243}$

This Note's analysis lias led to a conclusion consistent with Fejø's sentiments. While perfect imitation of the U.S. antitrust regime in Europe would undoubtedly be unsuccessful, there are nonetheless lessons to be learned fron the American antitrust experience which would be instrunental in European institutional re-

240. This phrase was coined in a speech given by Winston Churchill delivered in Zürich in 1946. See URWIN, supra note 46, at 2.

241. While European pohticians enjoyed using the United States as a model by which to showcase the advantages of economic integration, the two entities are politically very different. The European Union is a collection of treaties to which the Member States are signatories, see, e.g., EEC Treaty, supra note 4, while the United States is a constitutional republic.

242. See Lang, supra note 234 , at 458 .

243. FEJø, supra note 1 , at 8 . 
form-even if it were simply the opportunity to forego many of the mistakes the American system has wrestled with for a century.

\section{EUROPEAN COMPETITION REFORM IN PRACTICE}

\section{A. The European Cartel Office}

The prospective ECO should use the German system as a framework but this rigid system should be supplemented by aspects of other successful competition regimes. If resources allow, an independent institution to undertake monopoly and merger investigation should be established. This institution would be based upon the Englisl $\mathrm{MMC}$, but with more stringent requirements to cut down on the number and length of investigations. Also, because this "Euro-MMC" would be independent, it would reduce the effects of politicking in the EU by separating the prosecutorial and judicial roles. In addition, the competition system slould emulate that of the United States with regard to cooperation between state and federal entities and solutions to the transparency problem.

However, no nratter what systen is chosen to be the blueprint for an ECO proposal, now may not be the time for such dramatic reforn in European conipetition law. Premature reform miglit adversely affect the Community; DG-IV's experience and expertise, for instance, would be diluted by such a drastic institutional reform. ${ }^{244}$ Claus-Dieter Ehlernnann, the present Director General of DG-IV, has urged against the implementation of the ECO proposal at this time. He claims that 1) the current system is effective, efficient and respected;2) the criteria for referral of cases will liave to be expanded because political factors will come into play; 3) proceedings will no longer be so efficiently processed; 4) the ECO would be a political orplian which would have to build up its credibility; 5) the prestige of DG-IV would be undermined and the momentun1 of competition enforcement would waver; and 6) the reform would be costly. ${ }^{245}$

244. See Ehlermann, supra note 100, at 475-82.

245. See id. at 475-82. Wilks and McGowan also argue that the German model, upon which the ECO would most likely be based, would not work in the European context. See Wilks \& McGowan, Discretion, supra note 102, at 60-63. For discussion see notes 123-32 and accompanying text. 
The political reality of the situation is that the slow political machinery of the EU is not conducive to such dramatic reform. The Maastricht Treaty sets a slow pace, ${ }^{246}$ and changes have not come quickly in Europe. ${ }^{247}$ Competition law especially has been characterized by slow reform. ${ }^{248}$ Furthermore, the current proposal for an ECO is inadequate. A competent ECO would require several more years of research and planning. Accordingly, the $\mathrm{ECO}$, as a drastic institutional reform, should not be viewed as an ininediate solution to DG-IV's probleins but rather should be pursued as an effective long-range plan.

\section{B. Other Reform Options}

While the ECO is the most pohtically charged of the proposed competition reforms, other options do exist. Director-General Ehlermann suggests that many of the problems could be overcome within the present structure of DG-IV..$^{249}$ For example, DG-IV would becoine more effective if its staff was enlarged. ${ }^{250}$ Further, publication of DG-IV's opinions could improve transparency. ${ }^{251} \mathrm{~A}$ reform to emulate the American policy of public disclosure might effectively be adopted without costly institutional reform. ${ }^{252}$

Furthermore, perhaps an independent body could be set up within DG-IV, which would have the power of final decision, as in the proposed reform of the Enghish system. ${ }^{253}$ Several models for such reform were suggested in the debate over European merger control. ${ }^{254}$ However, this change was not iniplemented because, while this reform might create additional transparency, it would also lengthen enforcement procedures and create additional expenditures. ${ }^{255}$

246. See URWIN, supra note 46 , at $235-44$.

247. See id. at 245-62.

248. See notes 40,75 and accompanying text.

249. See Ehlermann, supra note 100, at $482-84$.

250. See Wilks \& McGowan, Disarming, supra note 8, at 271.

251. See Ehlermann, supra note 100, at 482-83.

252. See supra notes $232-33$ and accompanying text.

253. See supra note 167 and accompanying text.

254. See NEVEN, supra note 10, at 231-36 (explaining several different institutional frameworks suggested as models for a new EU competition regime).

255. See Ehlermann, supra note 100, at 483. 
Finally, an independent monopoly agency has been suggested. ${ }^{256}$ This has the advantage of singling out just one aspect of European coinpetition policy and through that agency garnering the advantages purported to be derived from the ECO. However, this proposal would suffer from many of the same problems that the ECO would, only on a smaller scale.

\section{CONCLUSION}

Modeling an European competition authority should be a priority for the EU. In light of the Union's changing situation, European competition reforin must begin soon. Any reform that is made should take into account the successes and failures of domestic systems in Europe and the United States. However, actual implementation does not appear imminent. ${ }^{257}$ European conupetition reformation is slow, ${ }^{258}$ and a proposal toniorrow will mean the establishment of a European competition authority years from now. Moreover, because inany of the Member States ${ }^{259}$ and the Commission $^{260}$ do not feel that the time is right to push for a European competition authority, the institutions of the European competition regime should settle for less drastic reforms for the time being.

256. See id. at $485-86$.

257. See Barber, supra note 237, at 2. The President of the BktAmt, Deiter Wolf, commented on the probability of implementing the ECO in the near future: "It won't probably happen before the end of the century." Id.

258. See, e.g., supra notes 40,75 and accompanying text.

259. See, e.g., Barber, supra note 237 , at 2 ; Wilks \& McGowan, Disarming, supra note 8 , at 264.

260. See Ehlermann, supra note 100 , at $475-81$. 
